\title{
1 1
}

هتطلبات تفعيل هنظوهة التدريب الإلكتزوني لتنمية أعضاء هيئة

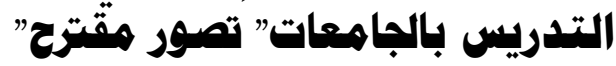

: إحلفاك

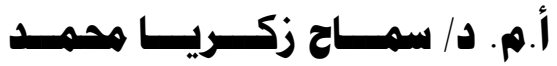

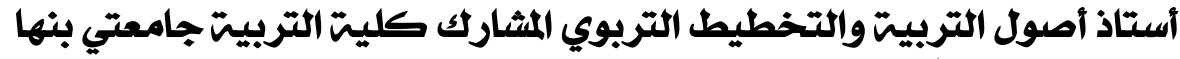
والإمام عبدالرحمن بن فيصل بالدئل والدمام بالسعوديتي 



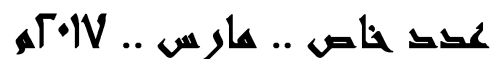

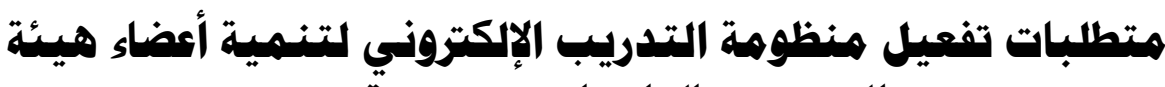

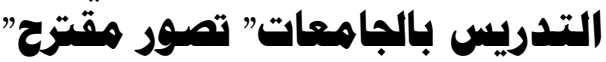

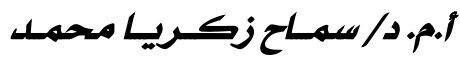

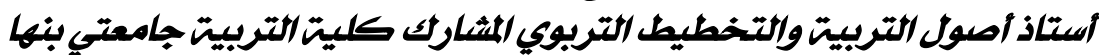 \\ والإمام عبلالكرحمن بن فيصل باللهمام بالسعوديتي
}

:

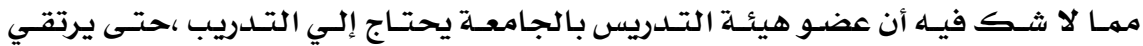

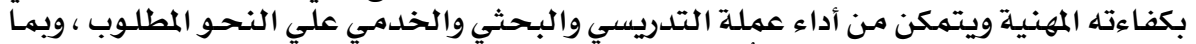

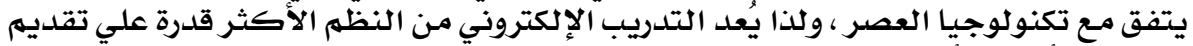

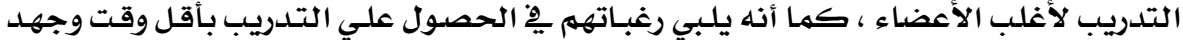

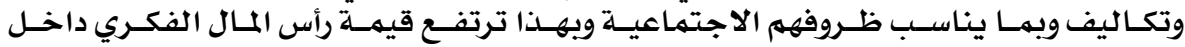

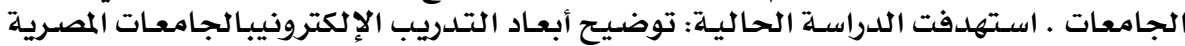

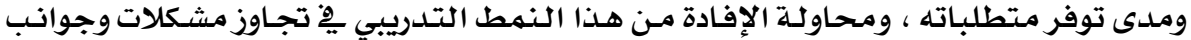

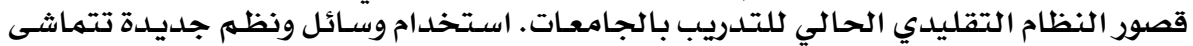

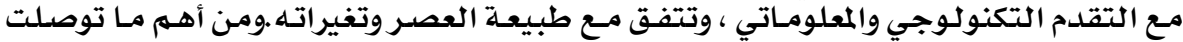

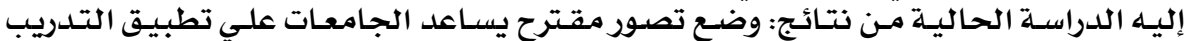

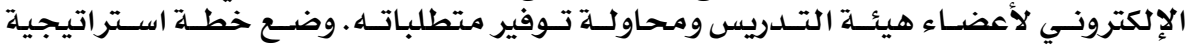

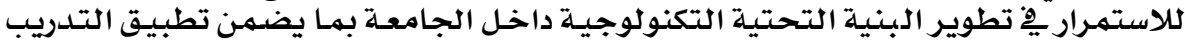

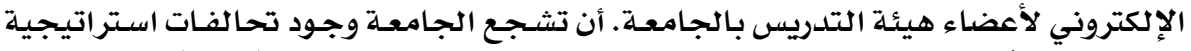

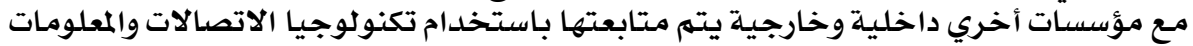
الحلديثة . موسيات

الكلمات المفتاحية: التدريب الإلكتروني -المتطلبات - الجامعات .

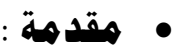

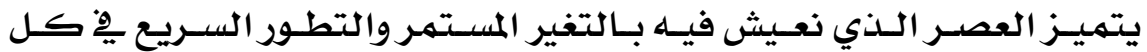

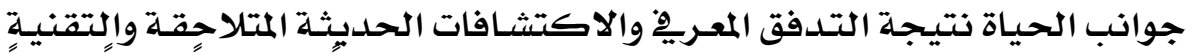

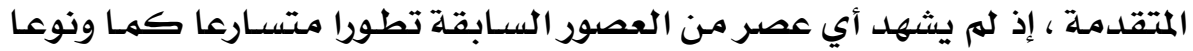

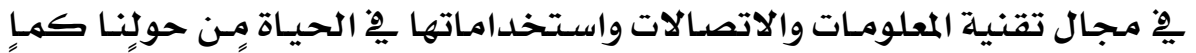

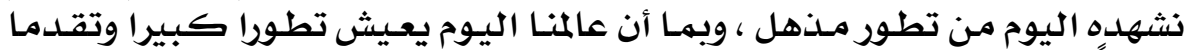

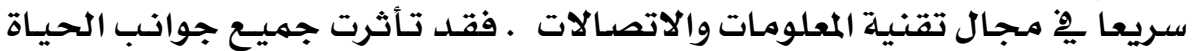

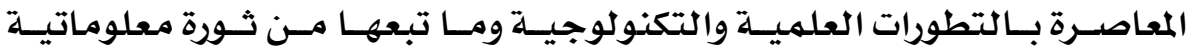

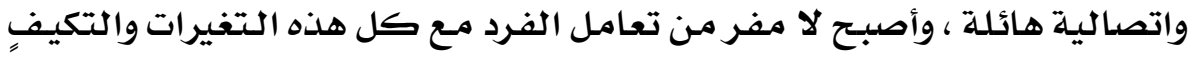

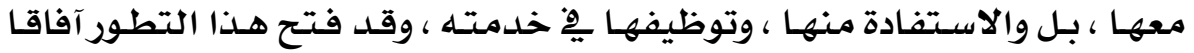

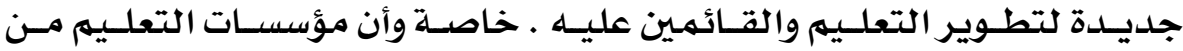

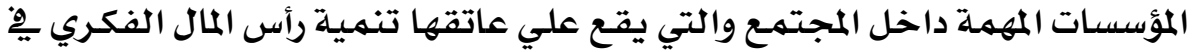

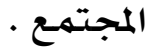

\section{MIV}




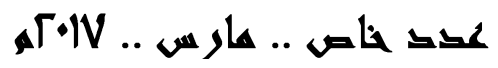

وبها أن مؤسسـات التعليهم العادي هي بهثابة معقل الفكر ، بحكمى وظـائف هـذه

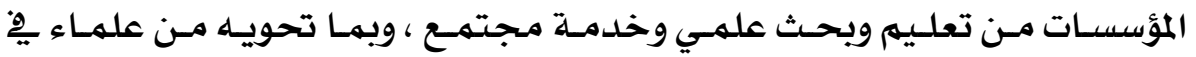

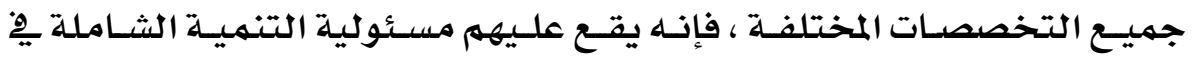

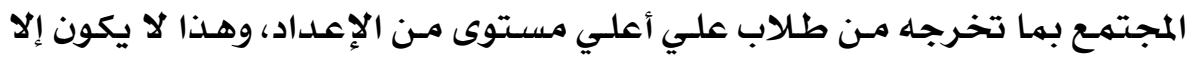

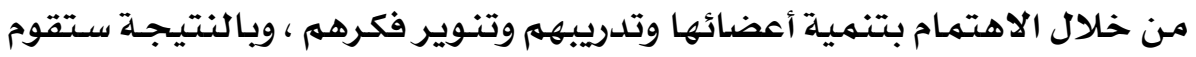

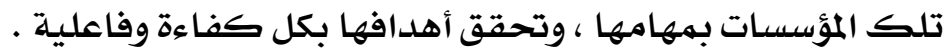

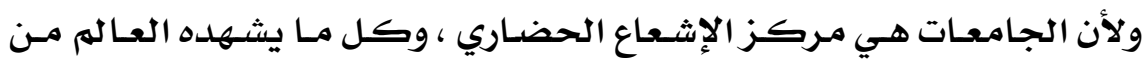

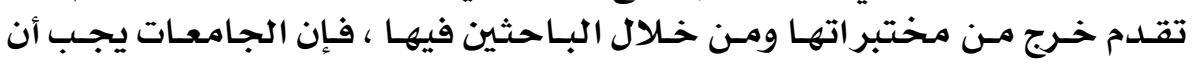

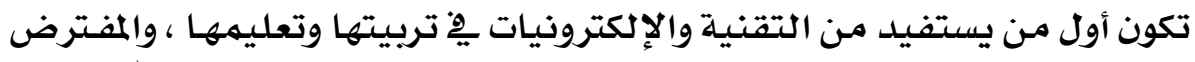

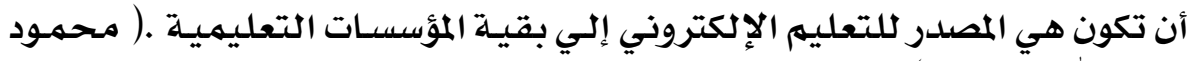

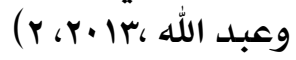

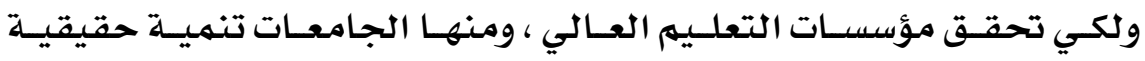

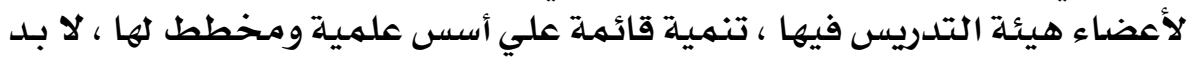

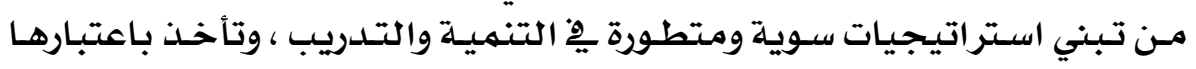

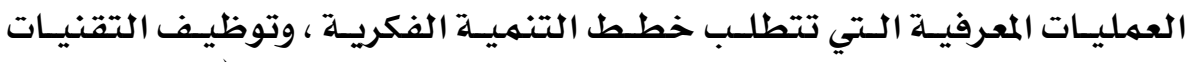

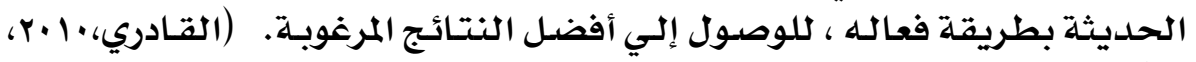

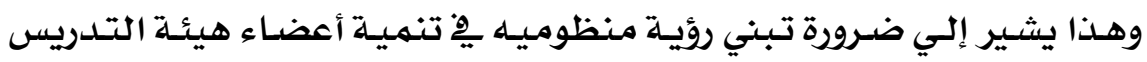

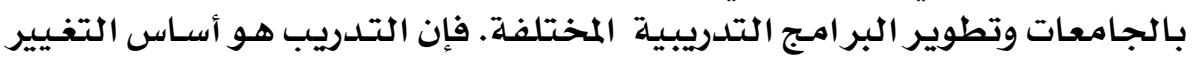

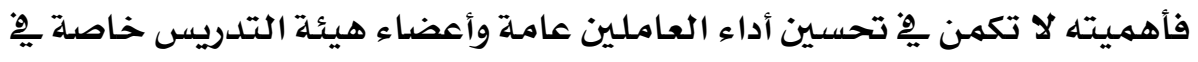

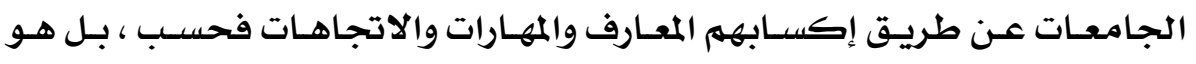

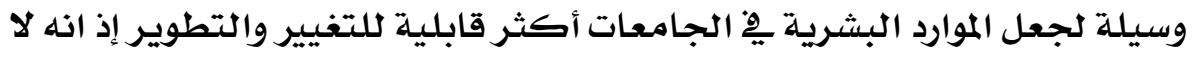
يهكن للتغيرات المخططة ِِّات الجامعات أن تُحدث الآثار الإيجابية المنشودة إلا مـن

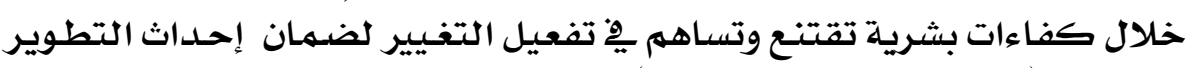

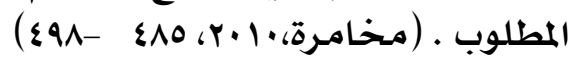

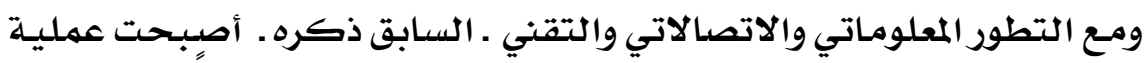

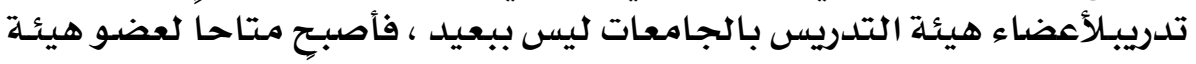

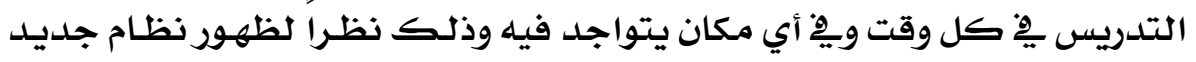
لتدريب ورفع مستوي رأس المال الفكري وهو نظام " التـدريب الإلكتروني " والذي ولذي

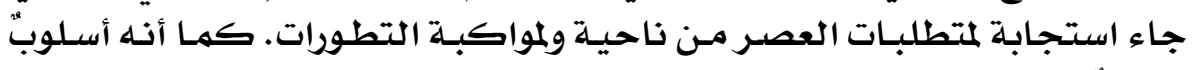

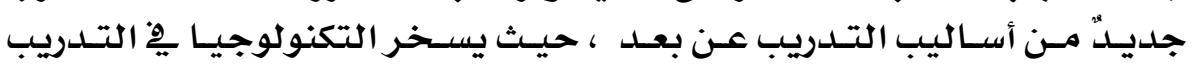

\section{MiN}




\section{אטכ خاص .. عار س .. VIיזم,}

باستخدام آليات الاتصال الحسيث ، التي تعدل وسيلة نشطة ، وتفاعليـة ، وعالمية

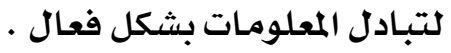

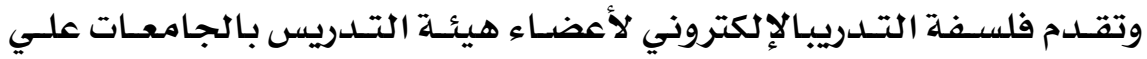

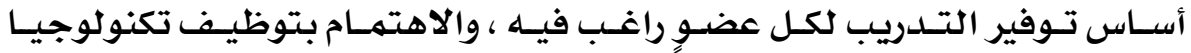

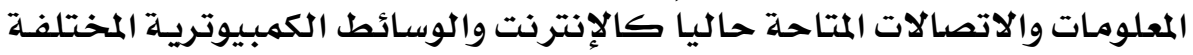

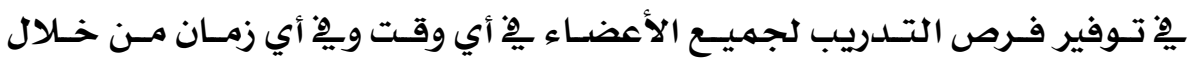
التدريب الإلكتروني الترون

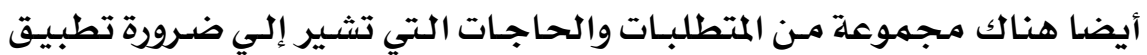

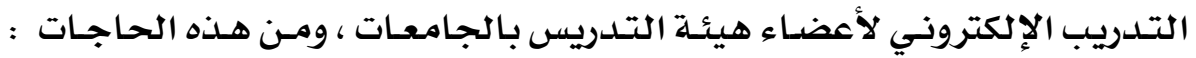

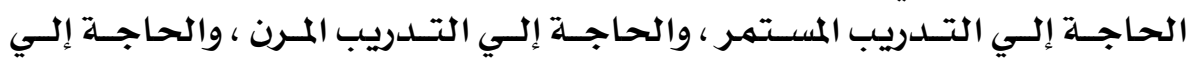

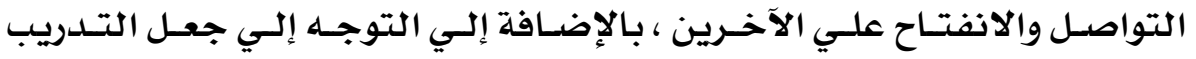

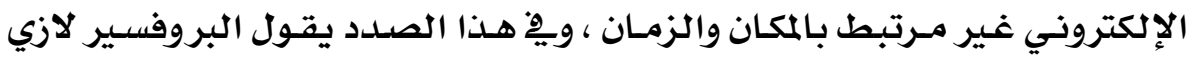

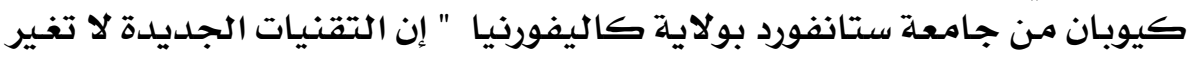

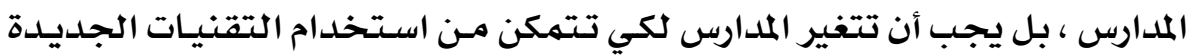

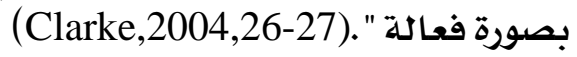

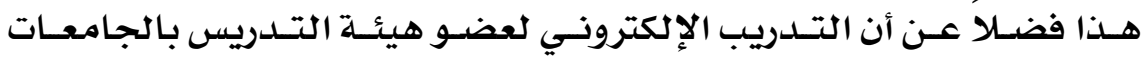

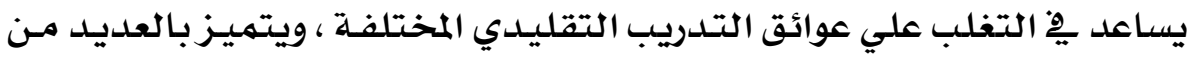

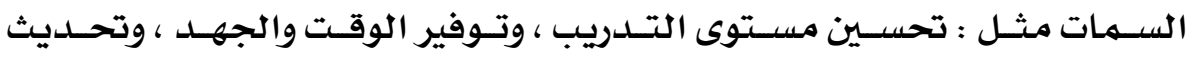

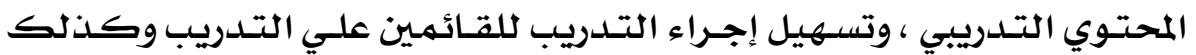

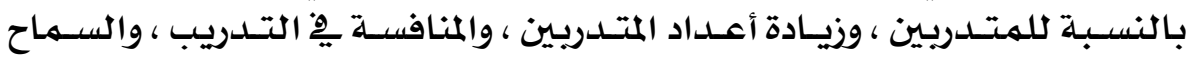

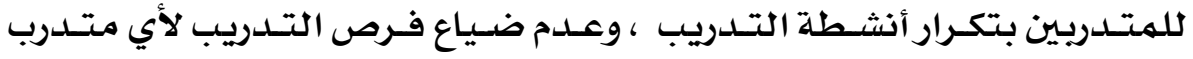

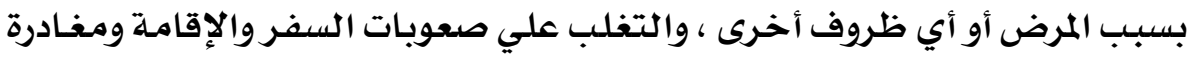

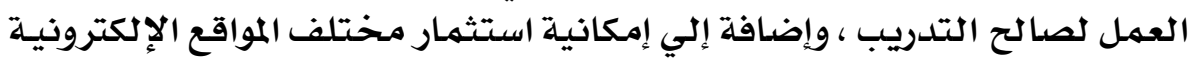

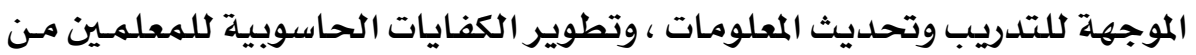

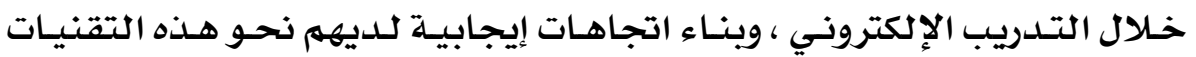

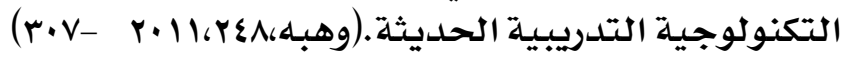

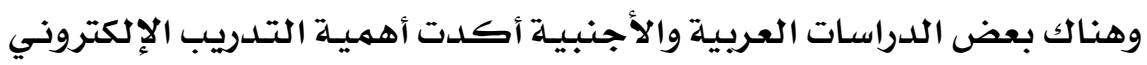

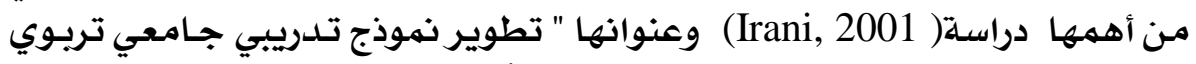

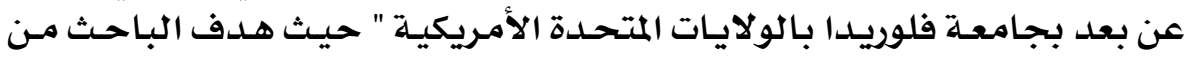

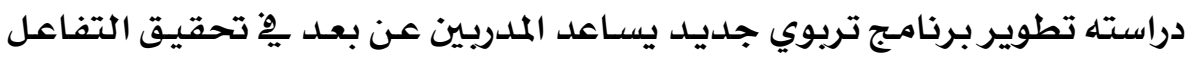

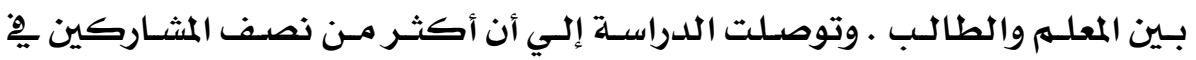

\section{M)}




\section{عقد خاص .. عار س .. IV اיم,}

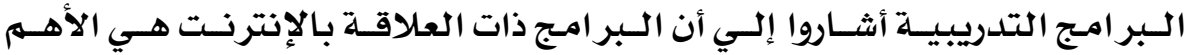

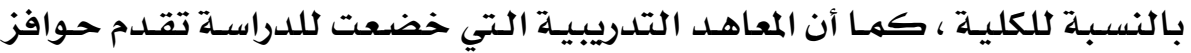

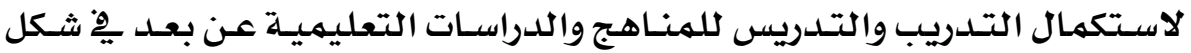

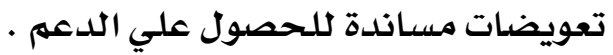

كما أكدت دراسـة ( Kilby,2001) بعنوان " اتجاه التدريب المبني علي شبكات

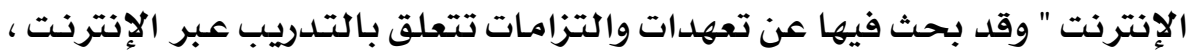

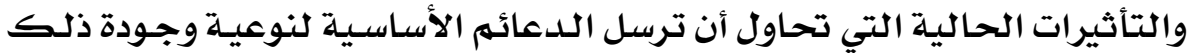

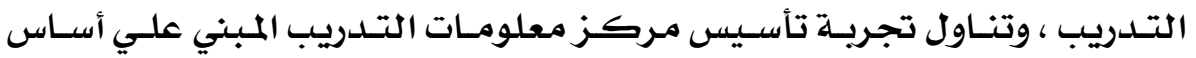

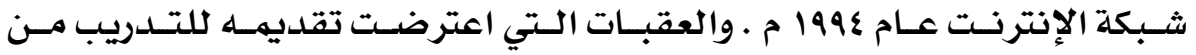

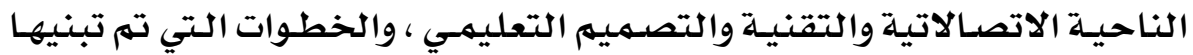

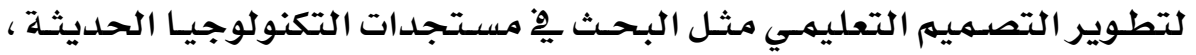

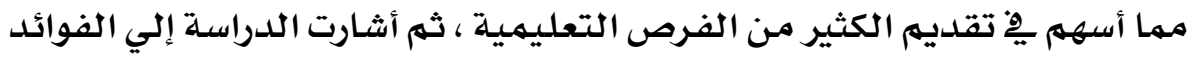

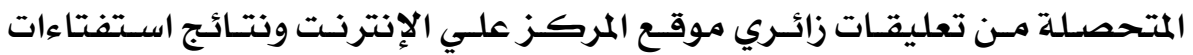

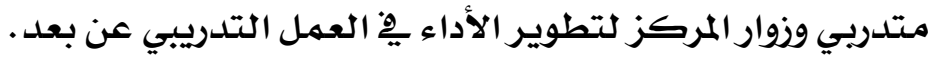

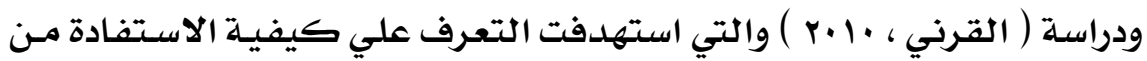

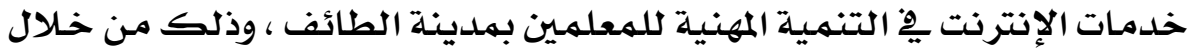

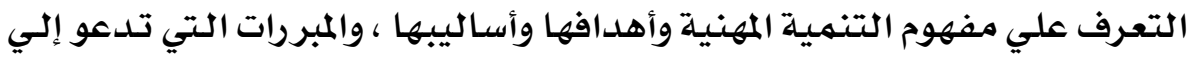

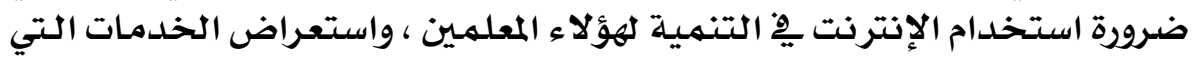

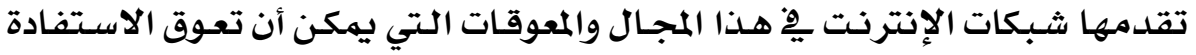

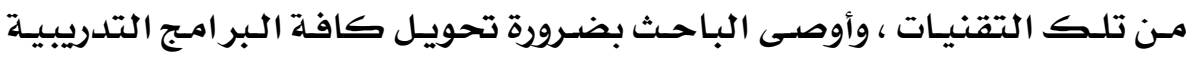

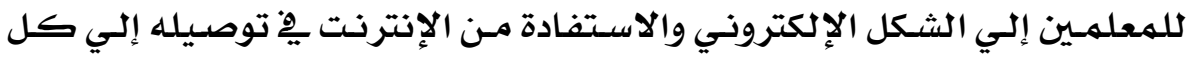

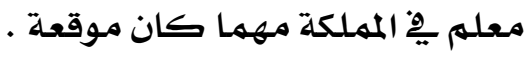

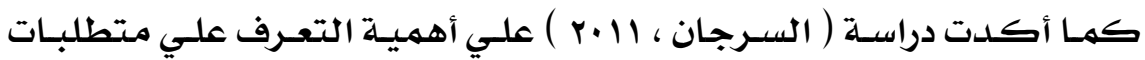

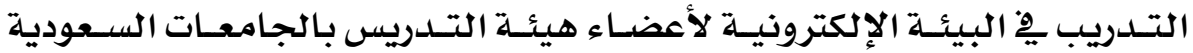

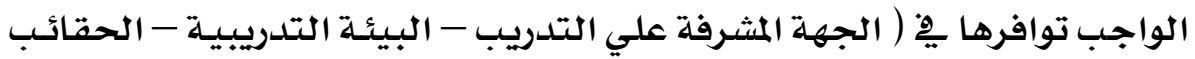

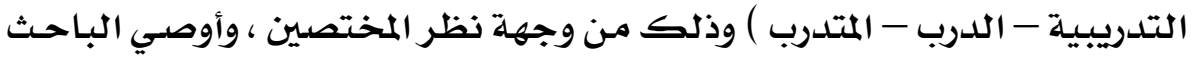

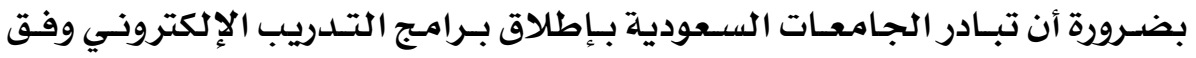

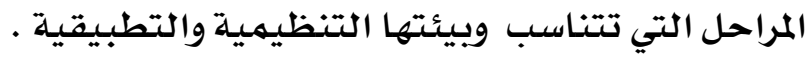

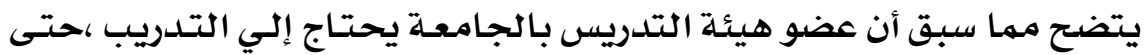

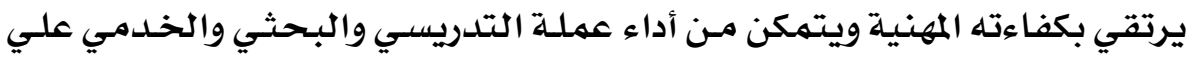

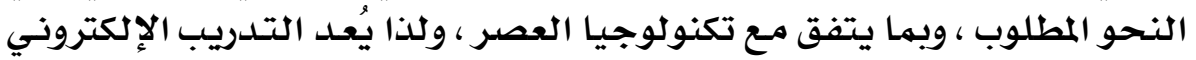

\section{YY.}




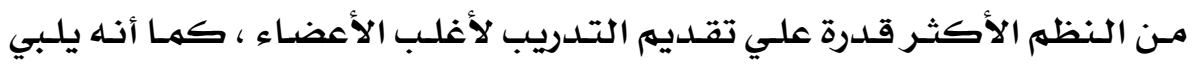

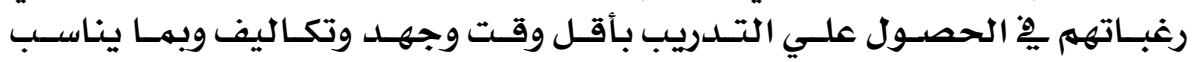

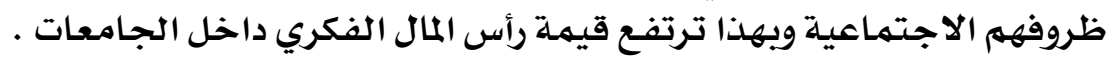

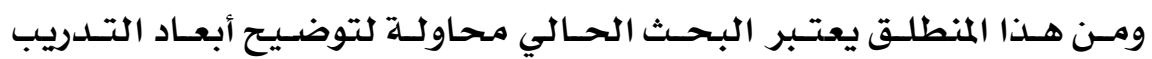

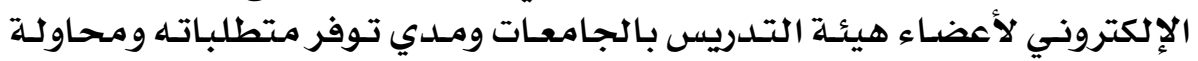

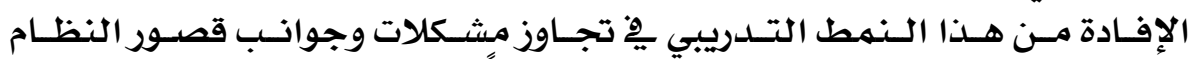

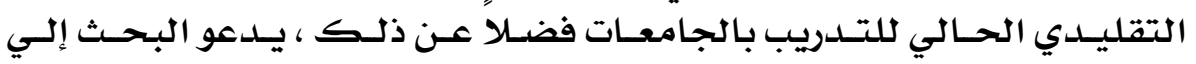

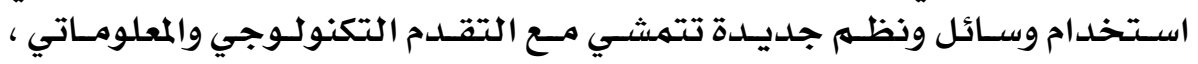
وتتفق مـع طبيعة العصر وتغيراته.

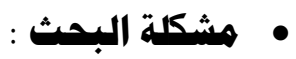

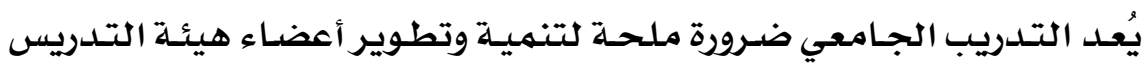

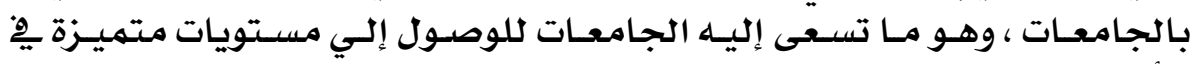

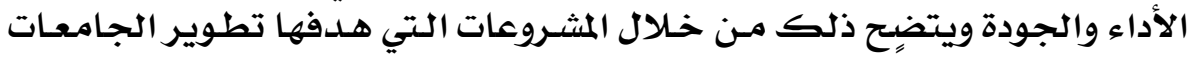

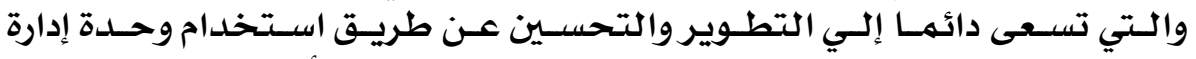

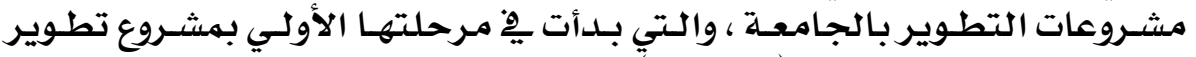

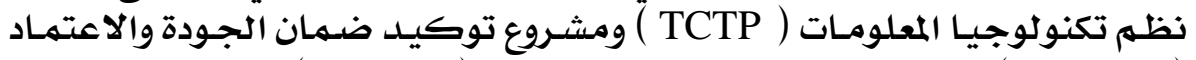

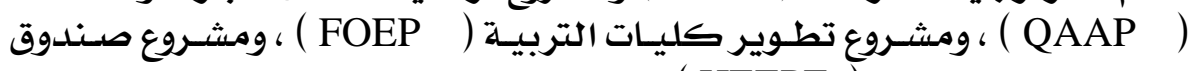

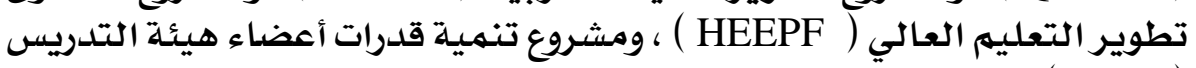

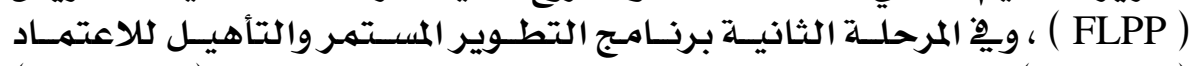

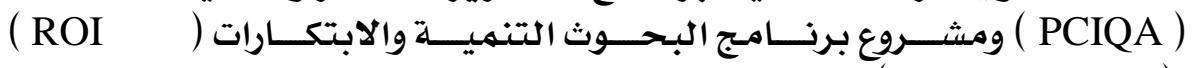
(www.bu.edu.eg).

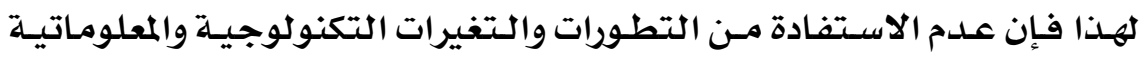

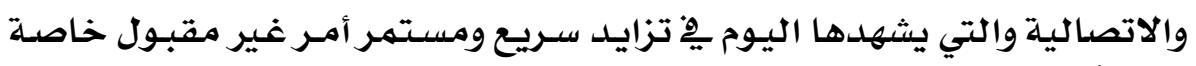

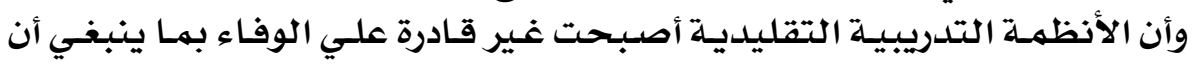

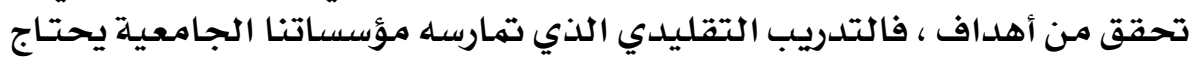

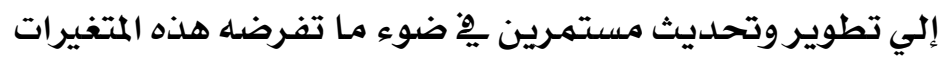

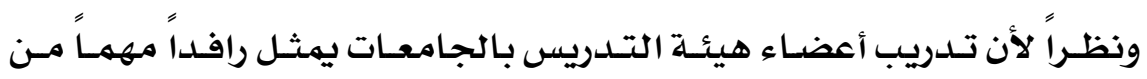

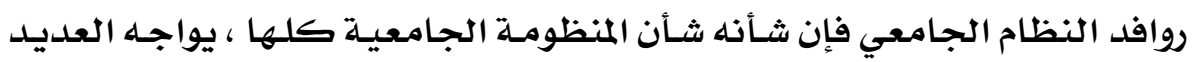

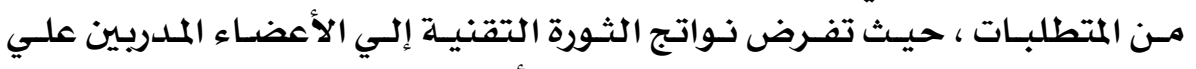

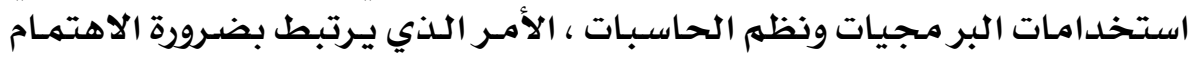

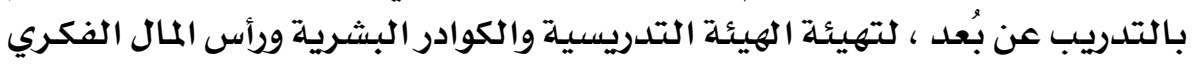

\section{MYI}




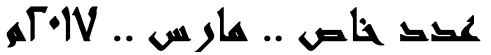

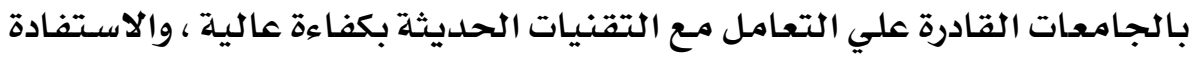

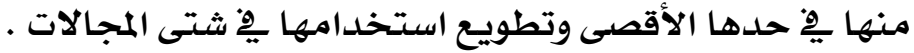

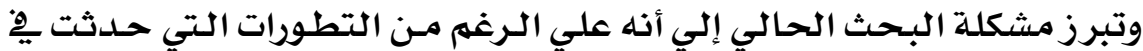

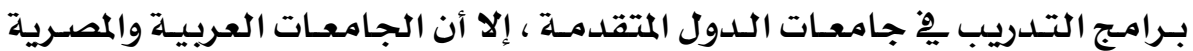

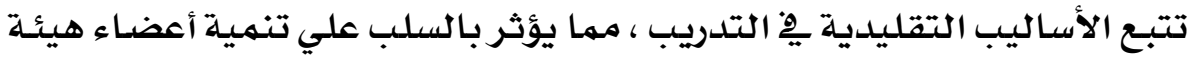
التدريس داخلها.

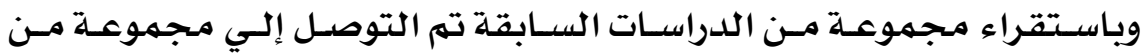

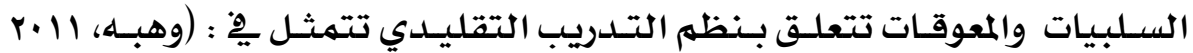

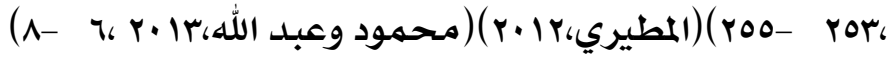

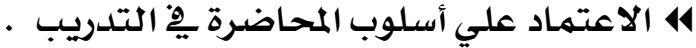

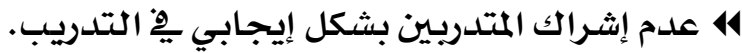

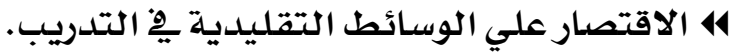

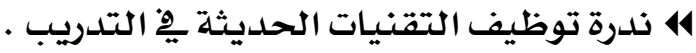

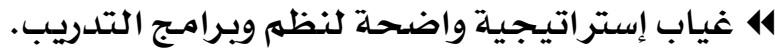
414 الذاتيـة.

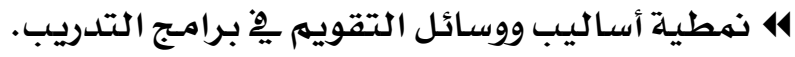

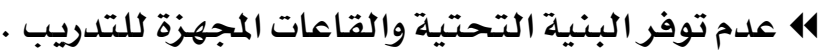

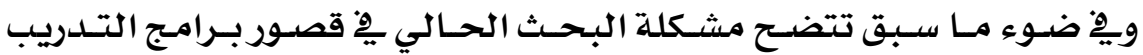

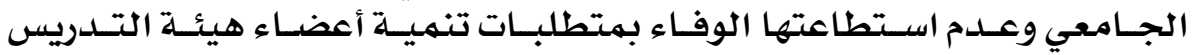
بالجامعات.

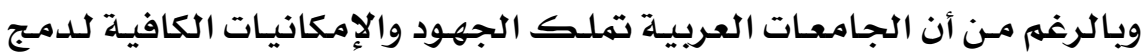

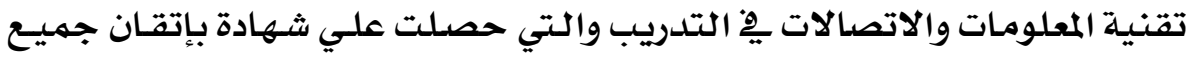

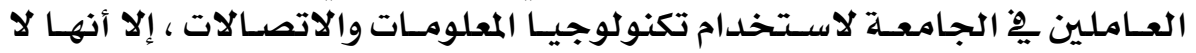

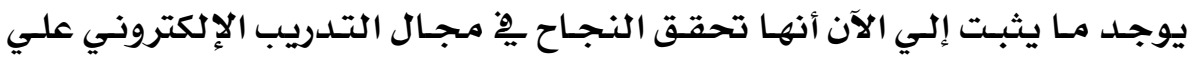

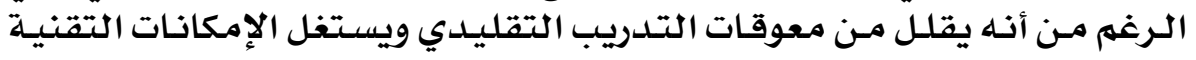

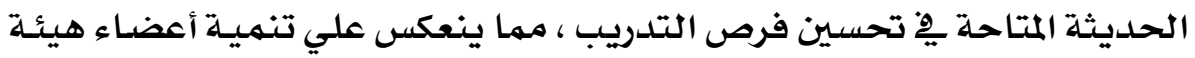

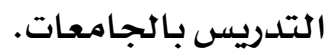

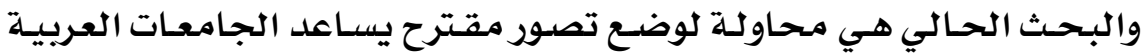

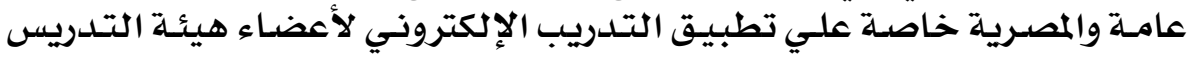

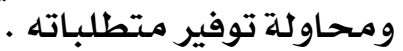

\section{MrY}




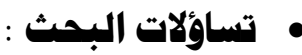

ينطلق البحث الحالي من تساؤل رئيسي هو :

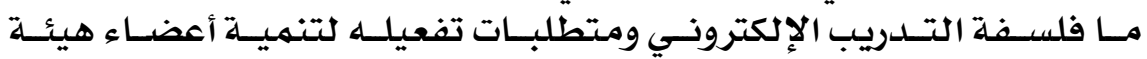

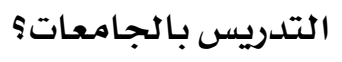

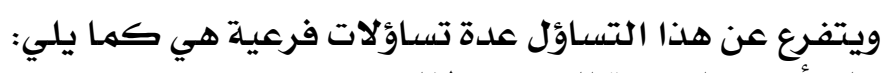

14 ما الأسس الفكرية للتدريب الإلكتروني ؟

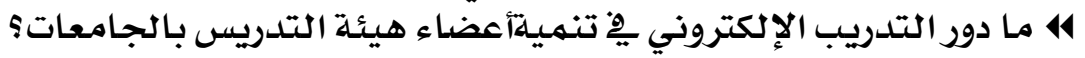

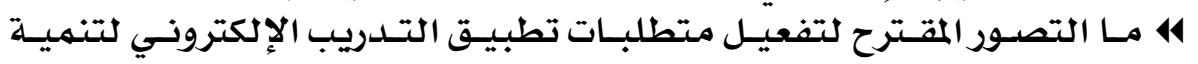

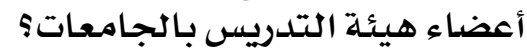

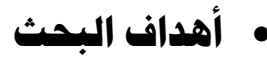

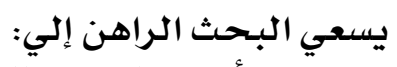

4 ه توضيح الأسس الفكرية للتدريب الإلكتروني.

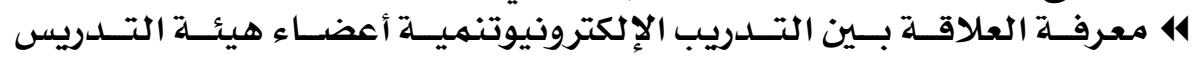

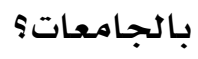

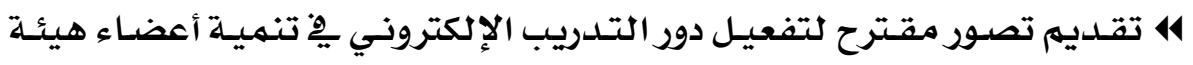

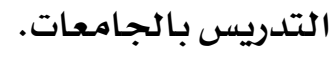

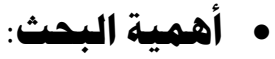

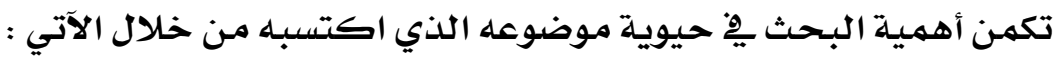

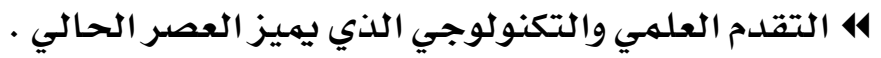

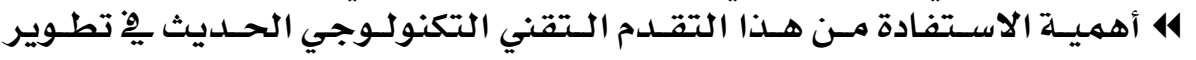

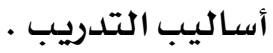

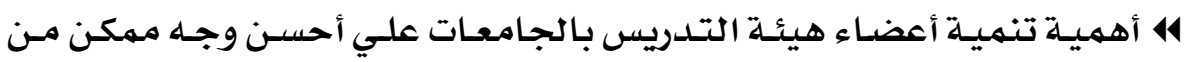

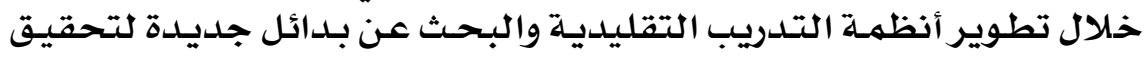

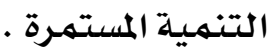
4 هقديم تصور مقترح لصناع القرار لتطبيق التدريب الإلكتروني لتنمية أعضاء

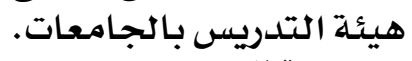

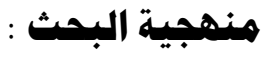

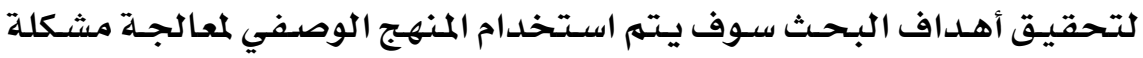

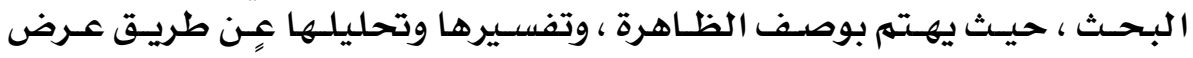

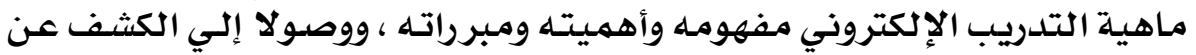

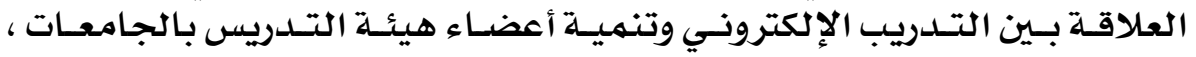

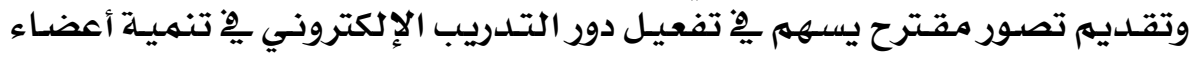

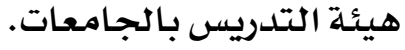

\section{TYM}




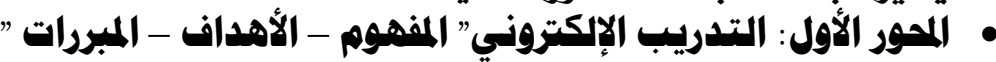

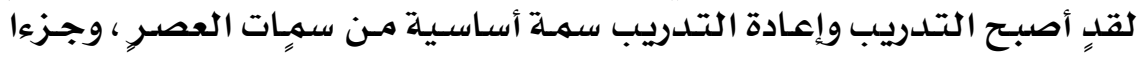

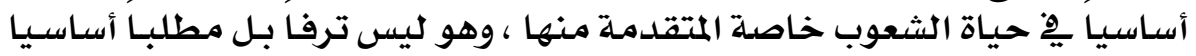

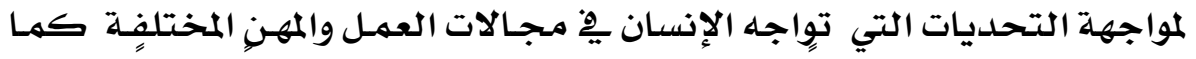

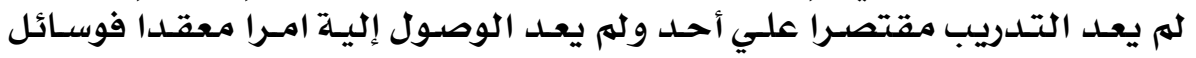

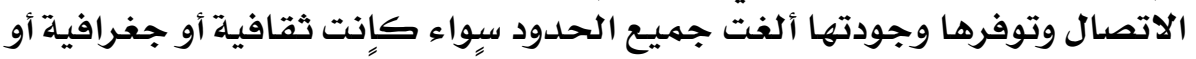

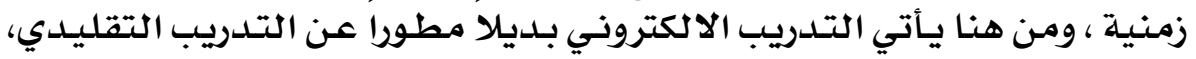

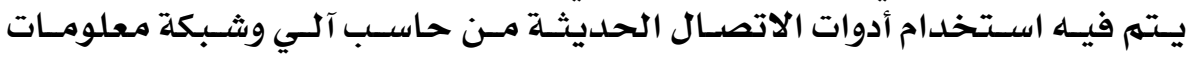

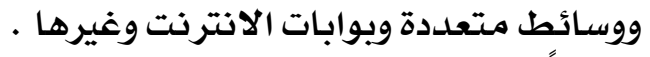

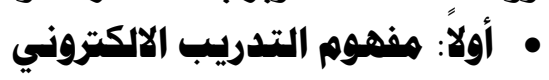

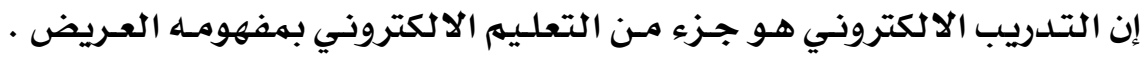

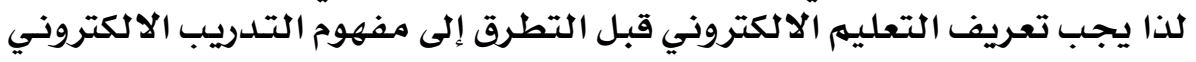

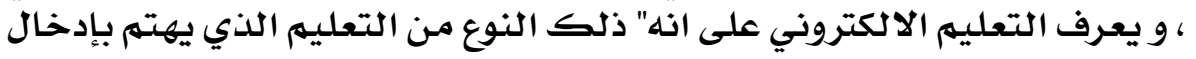

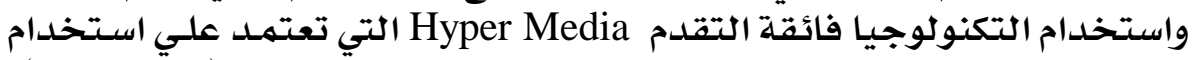

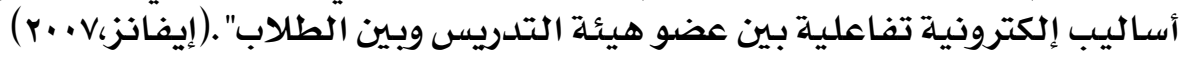

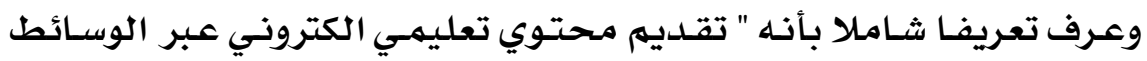

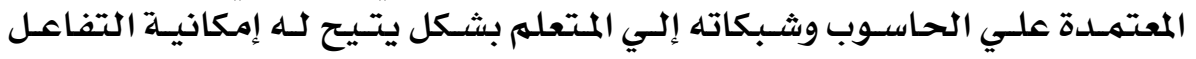

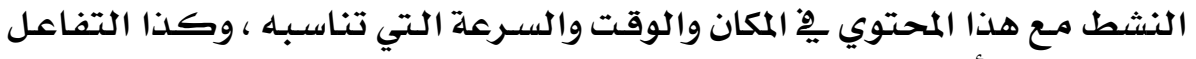

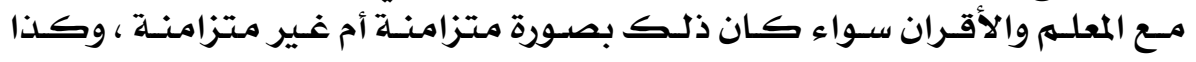

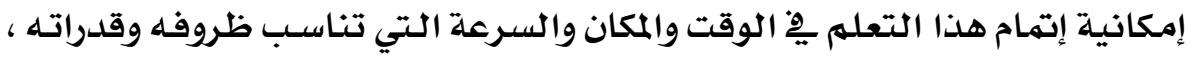

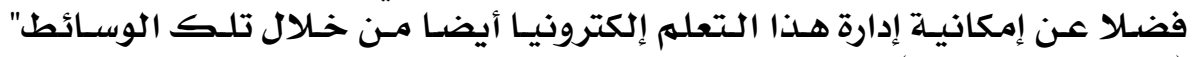

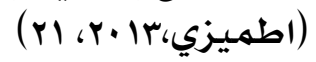

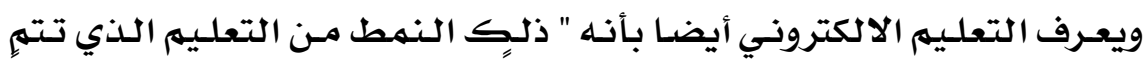

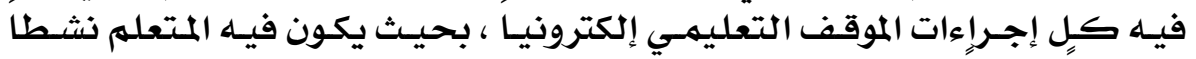

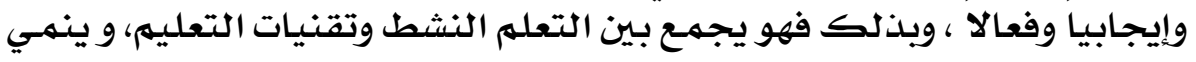

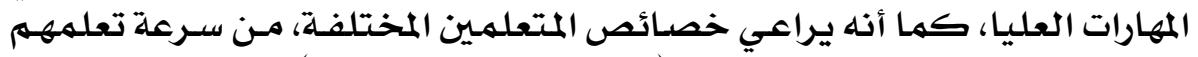

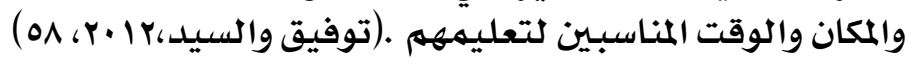

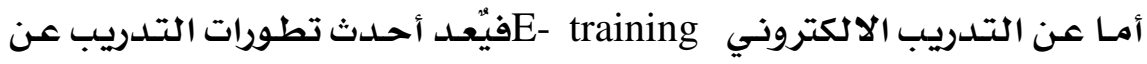

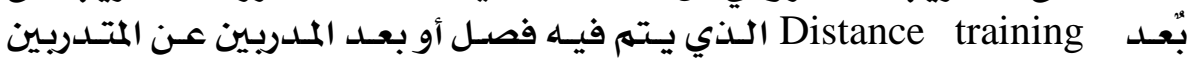

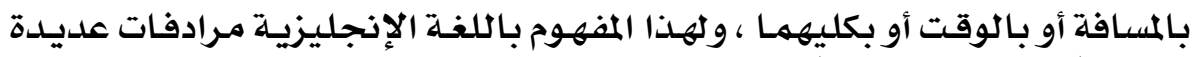

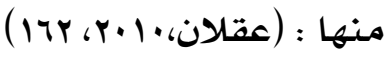

\section{rY}




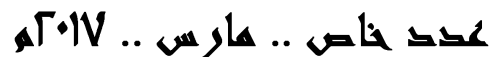

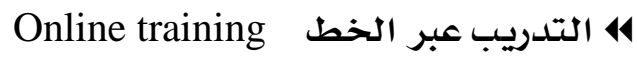

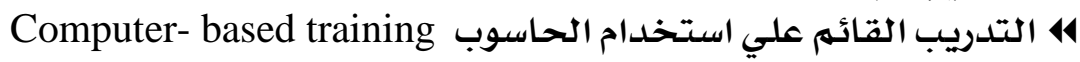

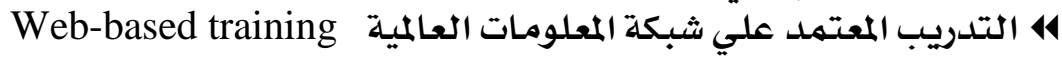

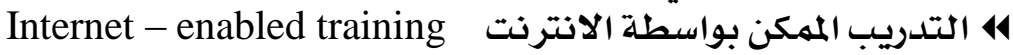
414 التدريب الافتراضي ونظراً لتعدد المرادفات تعددت مفاهيم التدريب الالكتروني : ل

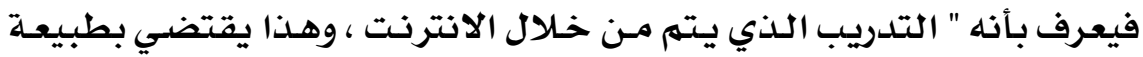

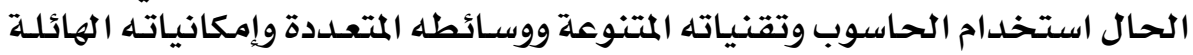

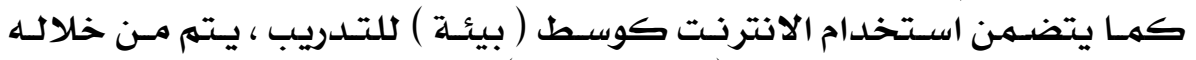

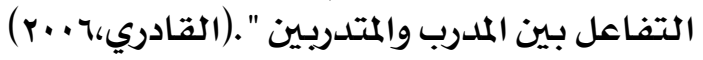

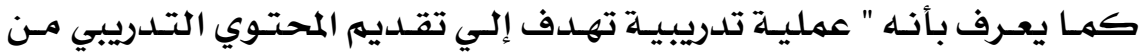

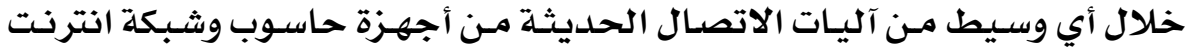

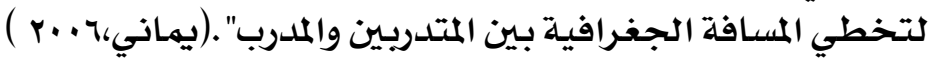

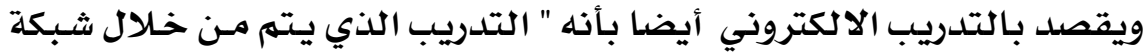

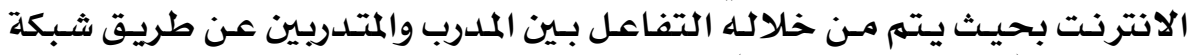

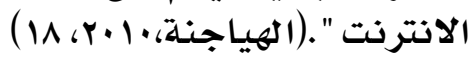

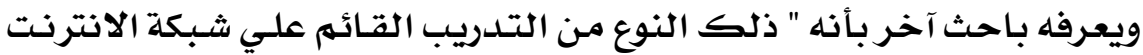

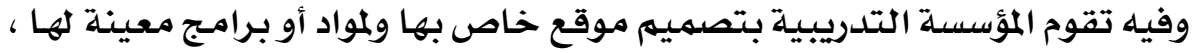

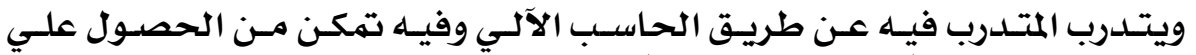

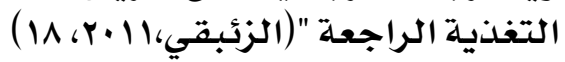

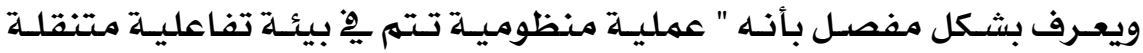

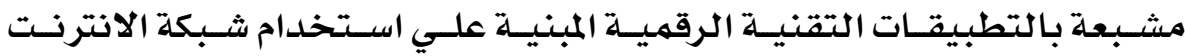

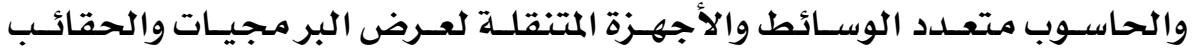

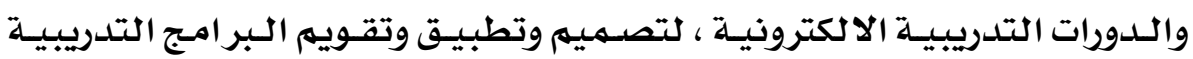

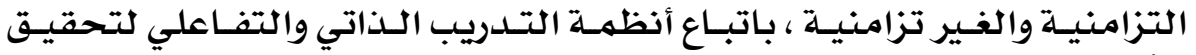

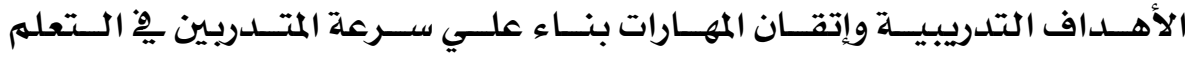

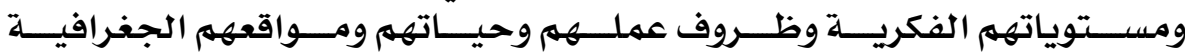

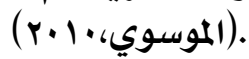

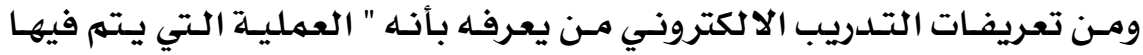

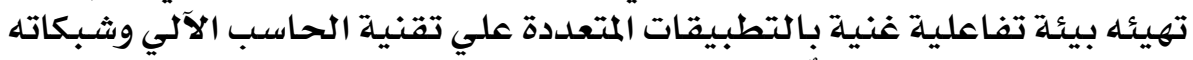

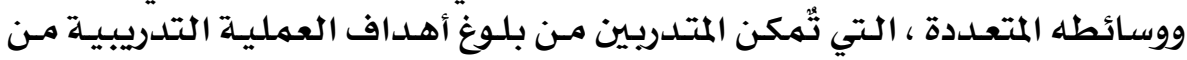

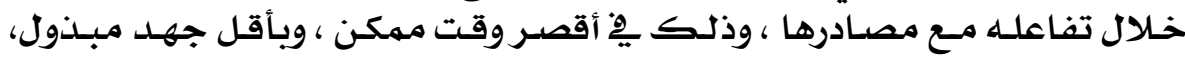

\section{YYO}

\section{أوراق عهل وبموث المؤتهر الدولي الأول لمركز تنسية قدرات أعضاء هيئة}

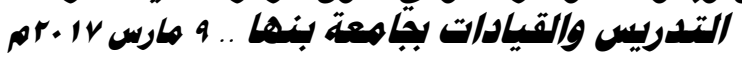




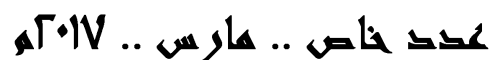

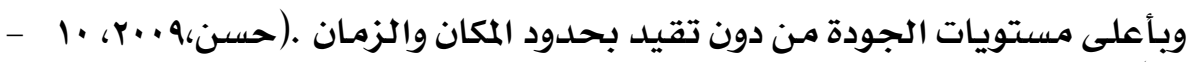

\section{• ثانياً: : أنهاع التدريب الالكتزوني}

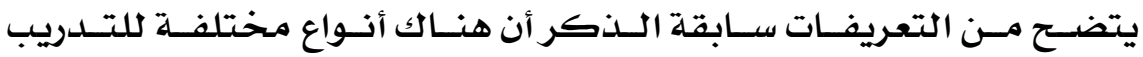

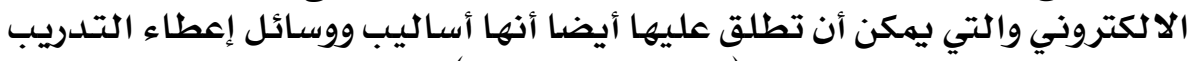

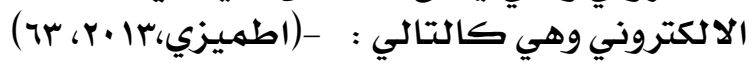

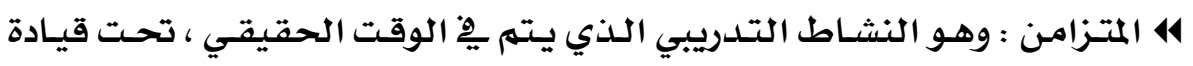

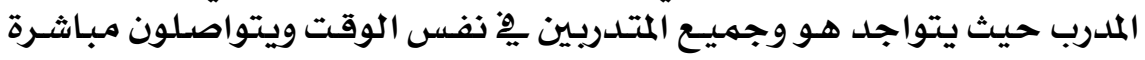

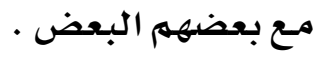

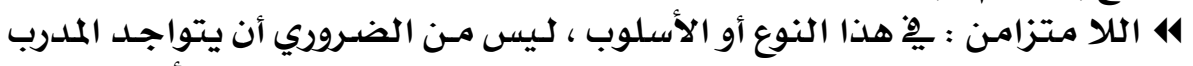

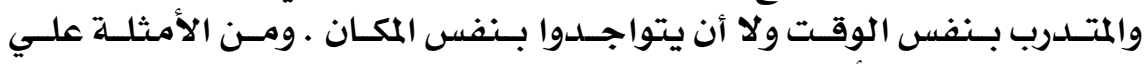

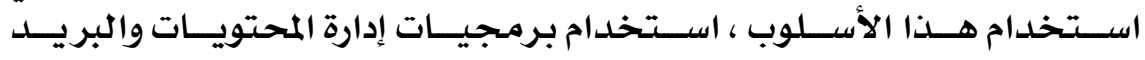

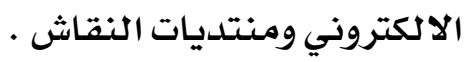

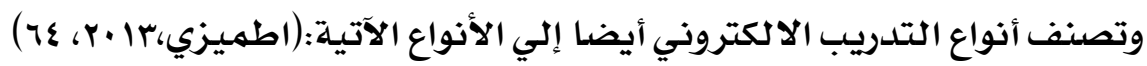

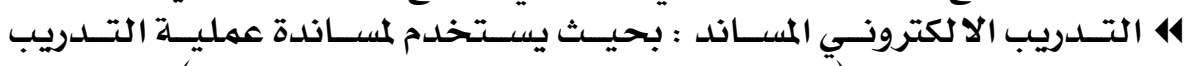

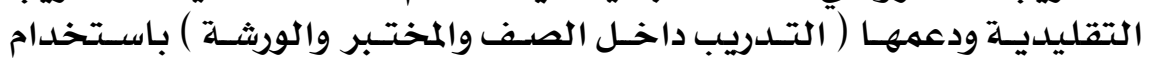

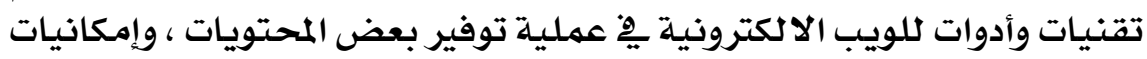

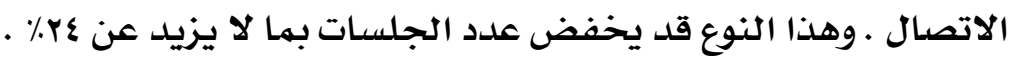

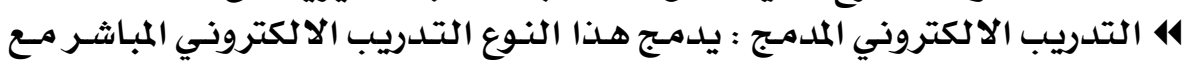

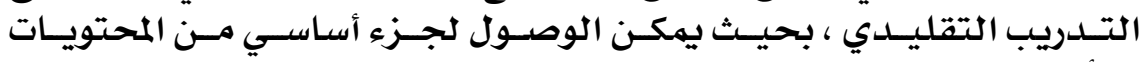

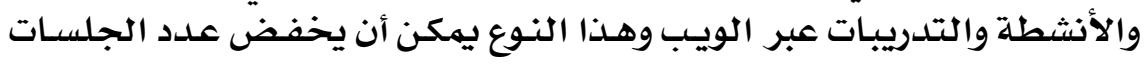

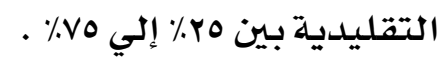

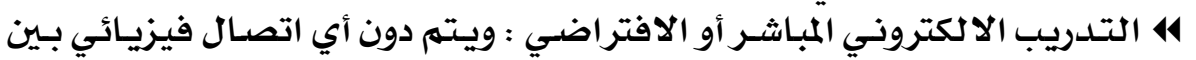

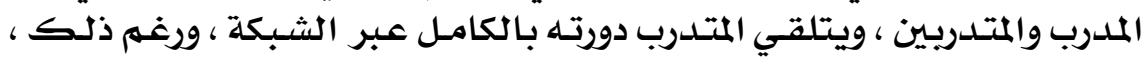

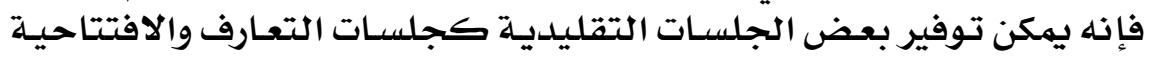

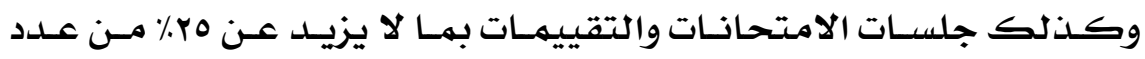

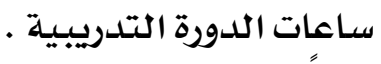

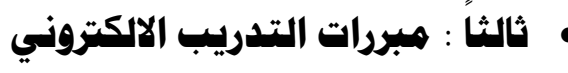

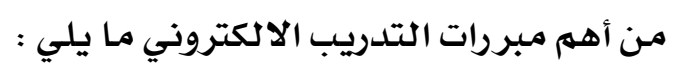

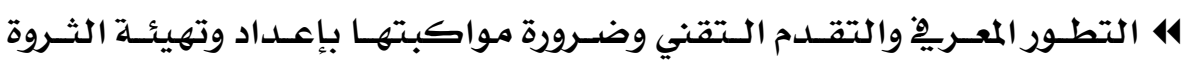

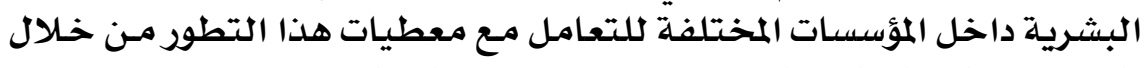

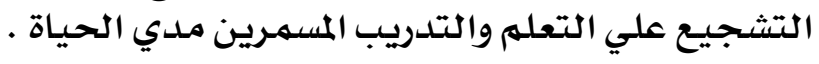

\section{rYT}




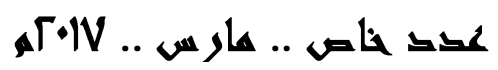

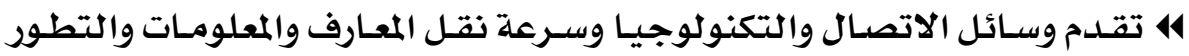

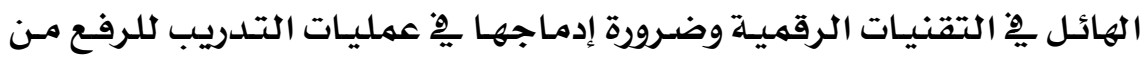
جودته باستمرار.

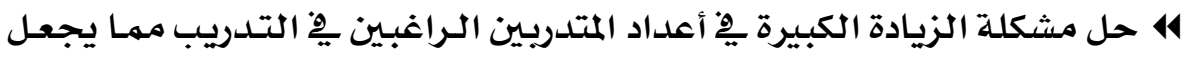
المسئولين عن التدريب عاجزين عن توفير التهادئ التدريب لهله الأعداد.

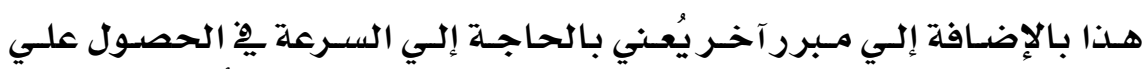

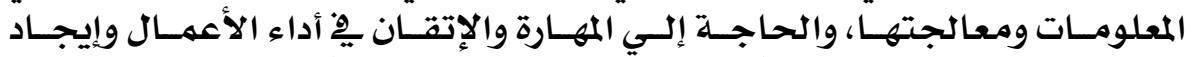

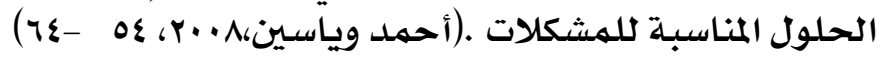

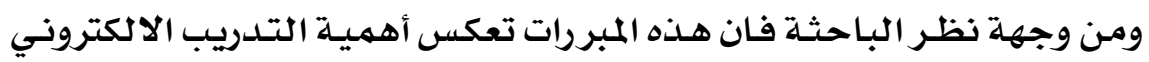

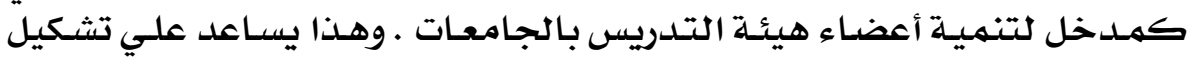

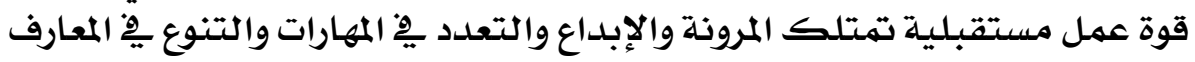

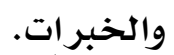
• رابعاً: : أهداف التدريب الالكتزوني

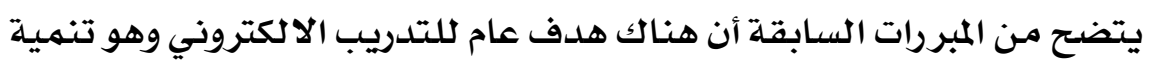

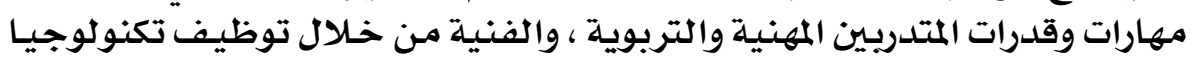

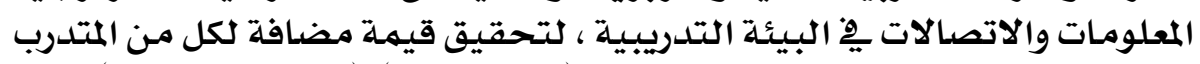

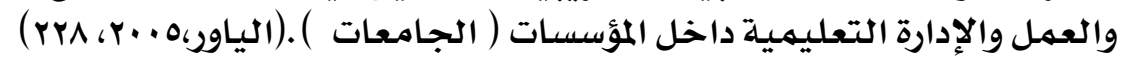

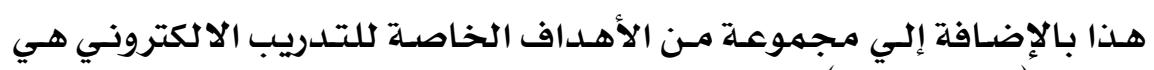

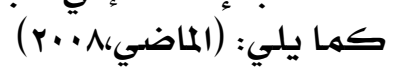

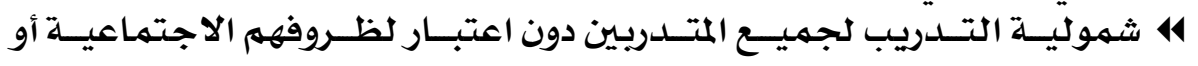

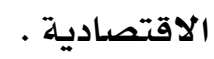

4 إيصال التدريب مباشرة إلي مواقع عملهم أينما كانوا .

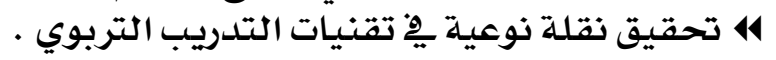

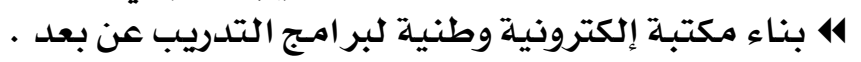

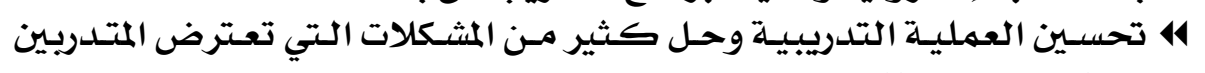

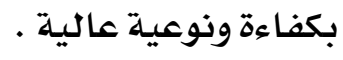

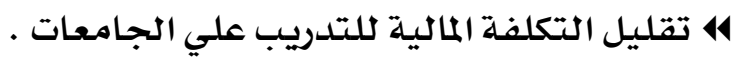

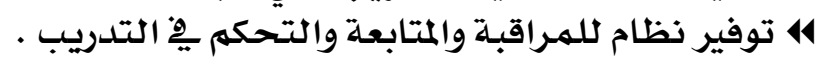

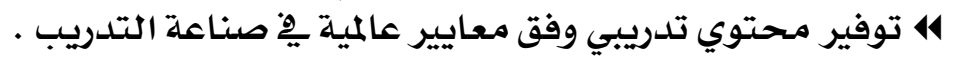

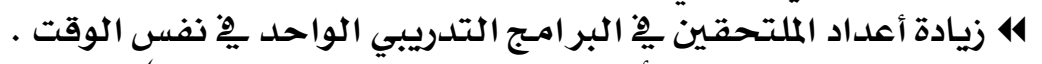

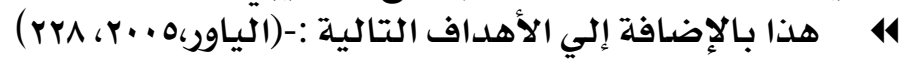

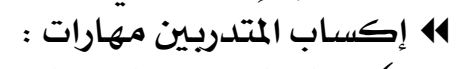

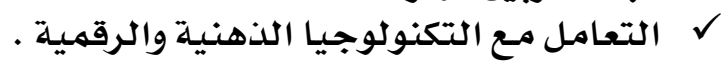

\section{rYV}




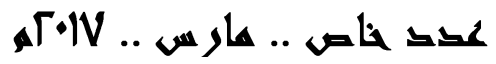

$$
\begin{aligned}
& \text { ل التعله الذاتي المستمر . }
\end{aligned}
$$

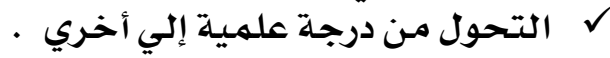

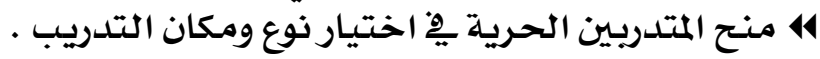

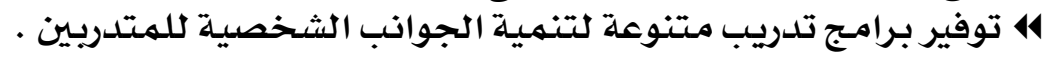

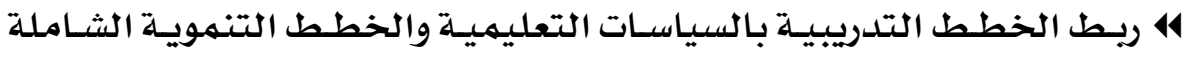

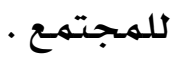

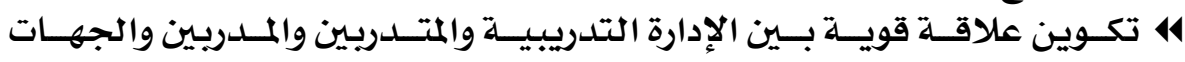

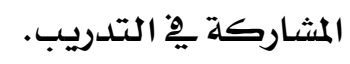

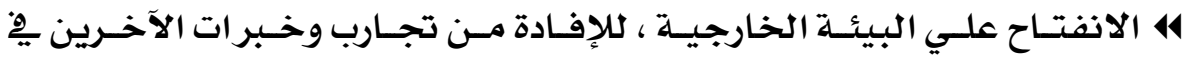

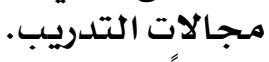

\section{• ماهسا : فوائد التدريب الالكتروني}

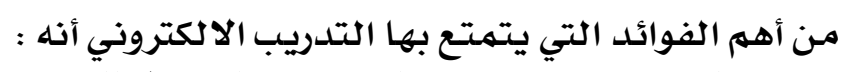

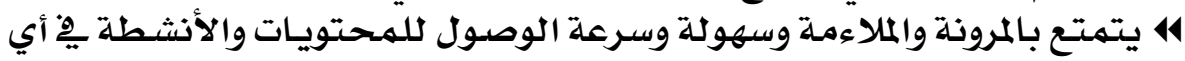

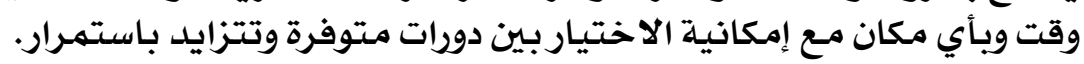

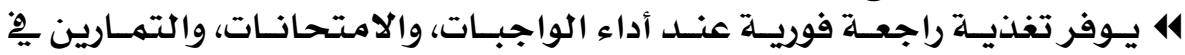

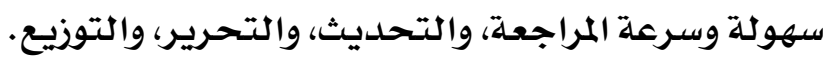

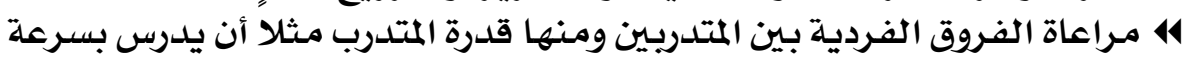

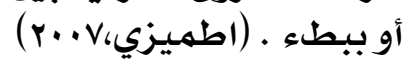

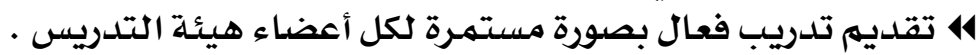

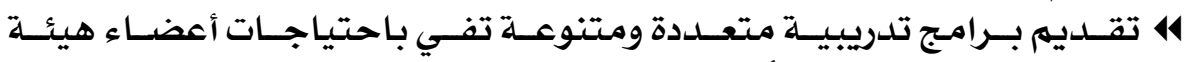

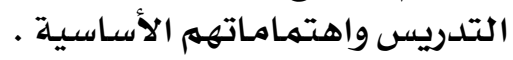

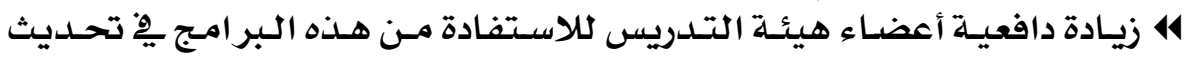

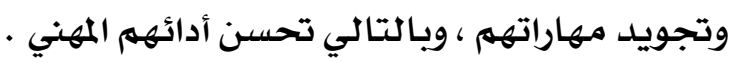

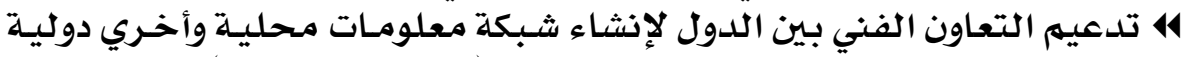

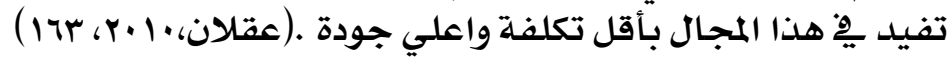

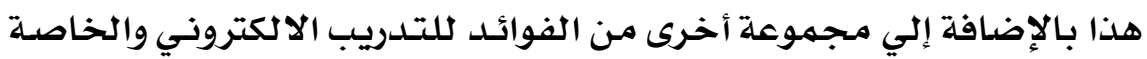

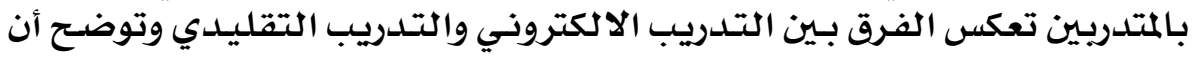

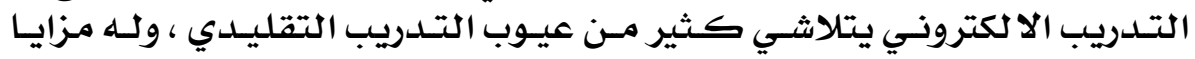

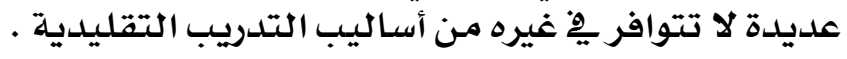

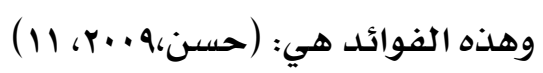

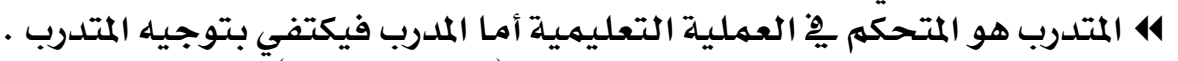

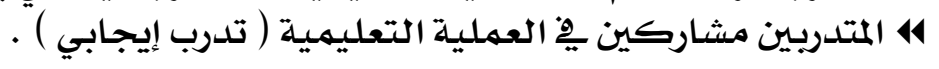

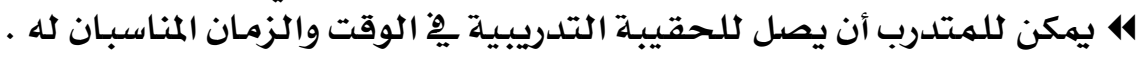

\section{rYA}


4 ينشئ التدريب الالكتروني علاقة تفاعلية بين المتدريسين والمدريبين .

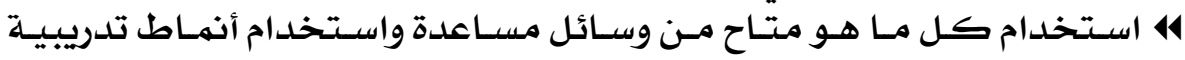

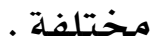

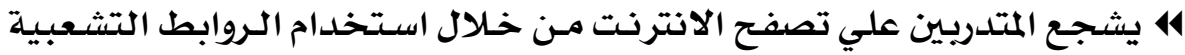

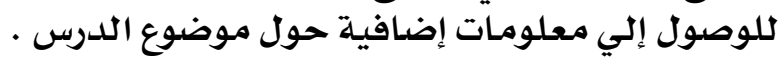

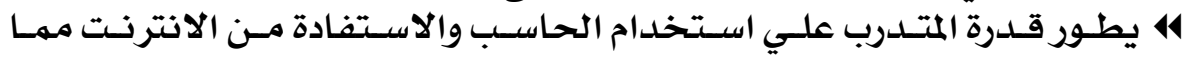

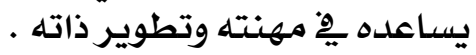

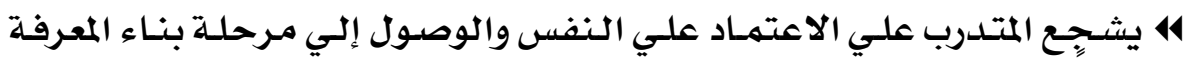

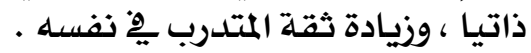

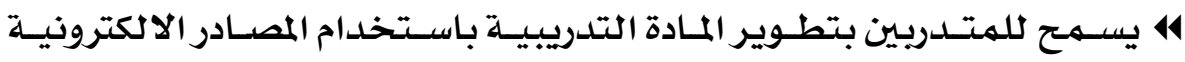

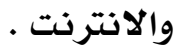
4 يسمـح للهدربين بالاحتفاظ بسجلات المتدربين والعودة لها يِّا أي وقت ومـن أي

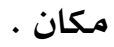

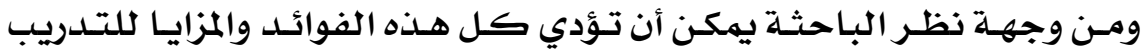

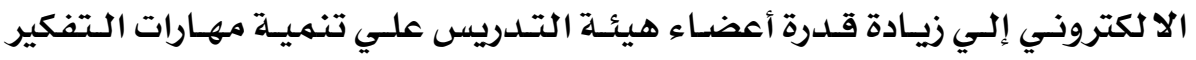

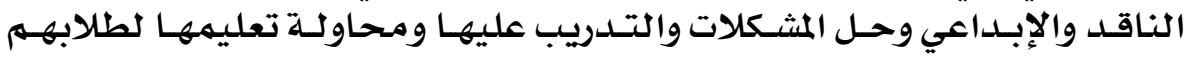

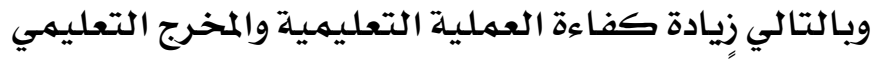

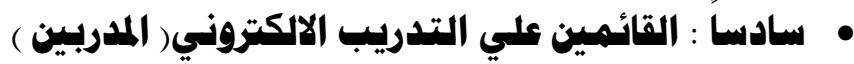

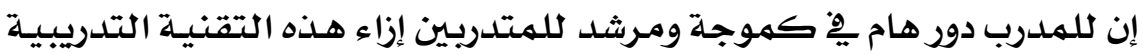

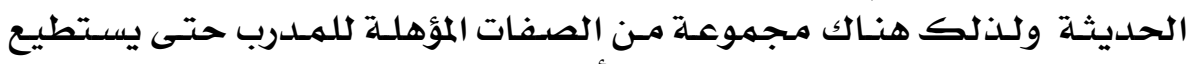

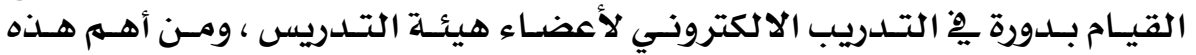

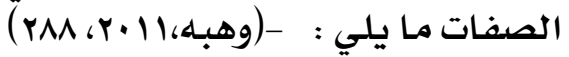

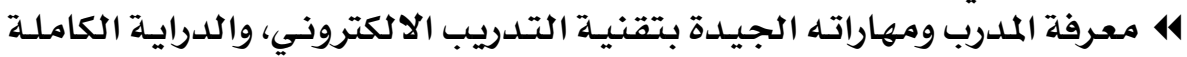

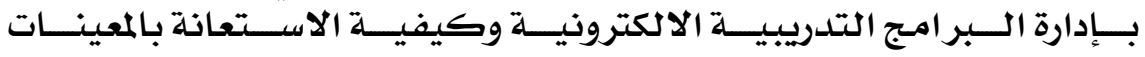
التكنولوجية بكفاءة.

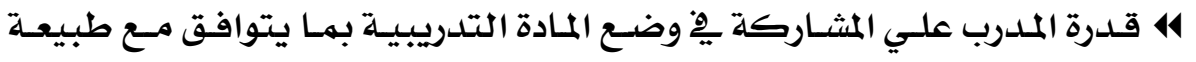

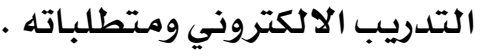

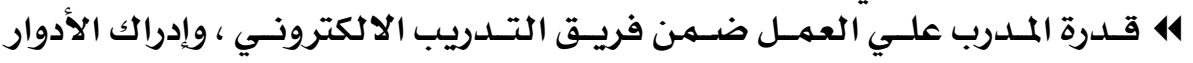

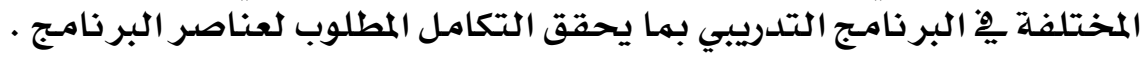

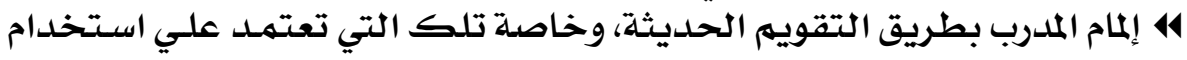

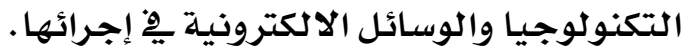

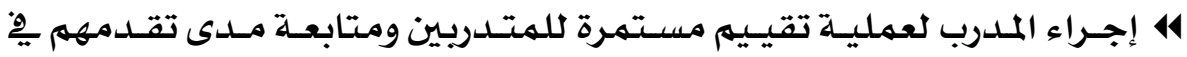

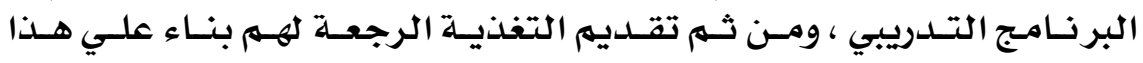

\section{rYq}




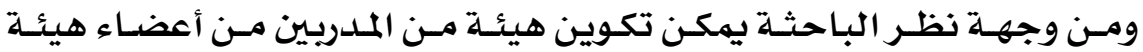

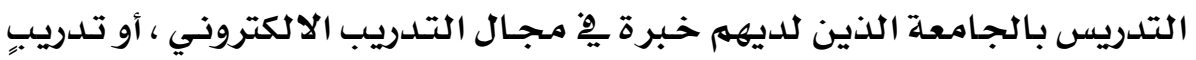

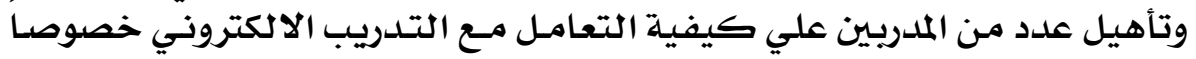

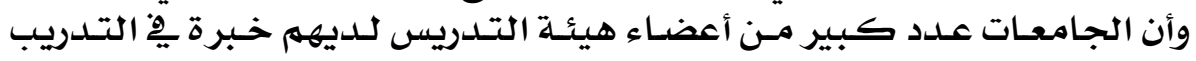

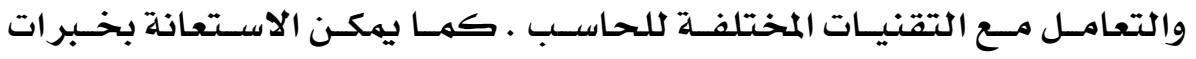

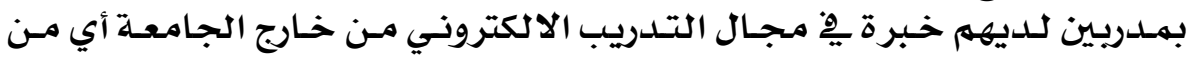

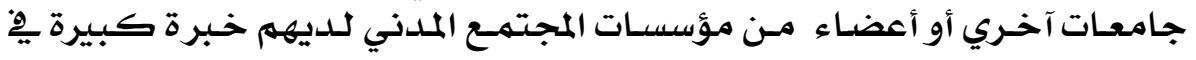

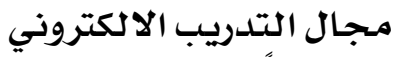

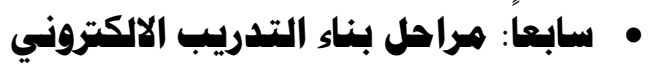

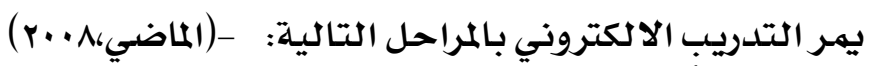

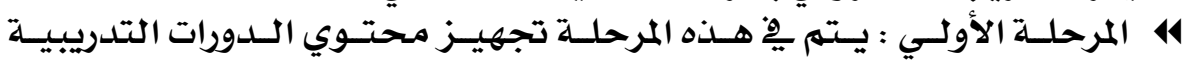

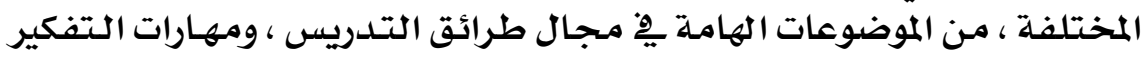

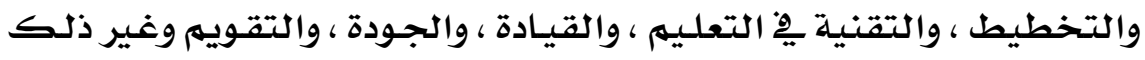

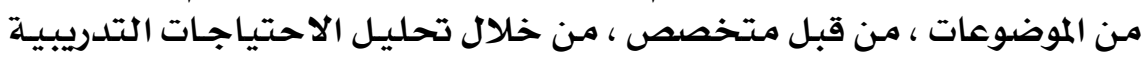

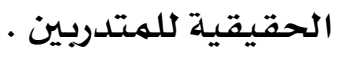

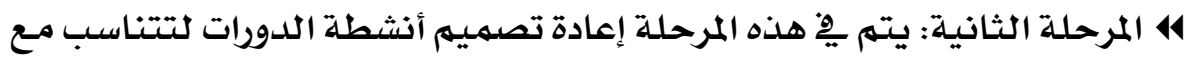

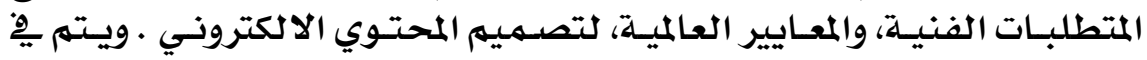

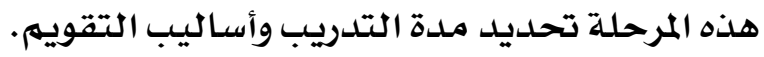

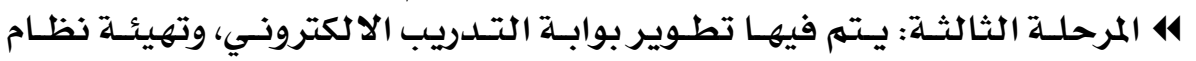

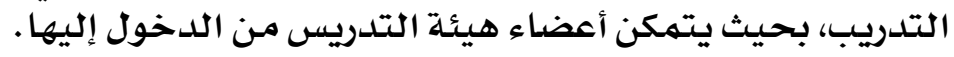

هـذا بـالإضـافة إلـي البـحث عـن بعض الأسـاليـ التقويهيـة المناسـبـة لطبيعـة

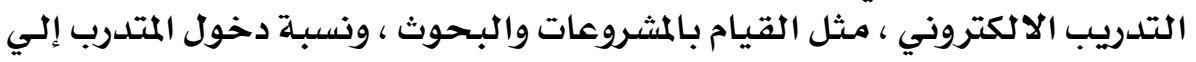

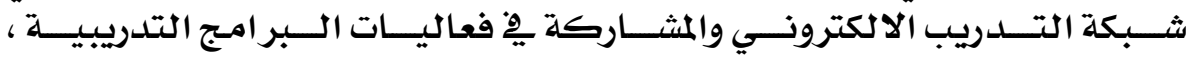

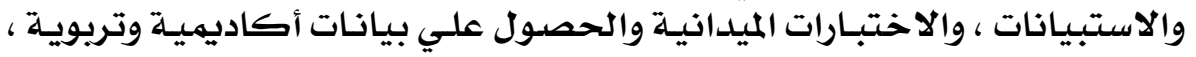

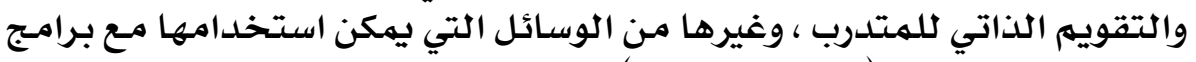

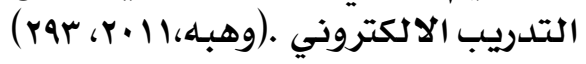

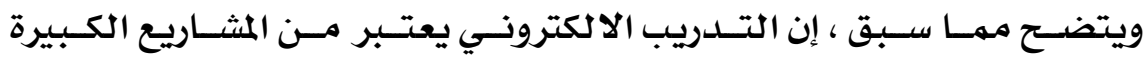

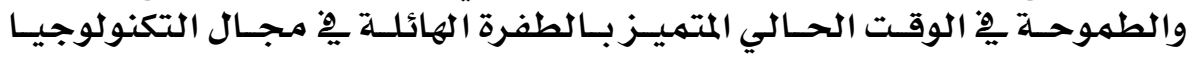

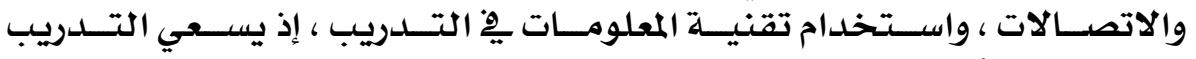
الا لكتروني لتأهيل وتطوير أعضاء هيئة التدريس بالجـامعات بـاعتبـارهم رأس مال

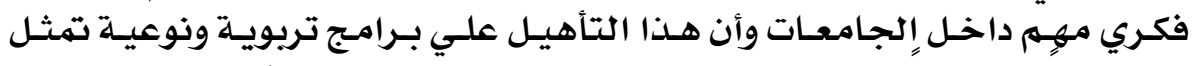

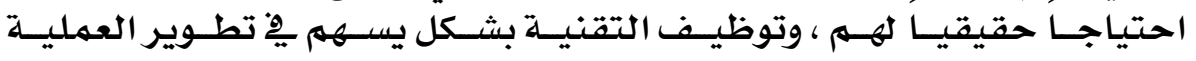

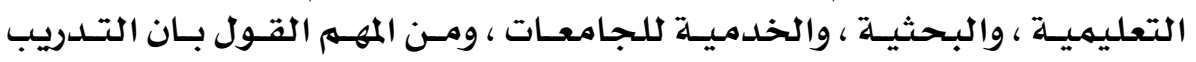

\section{rr.}




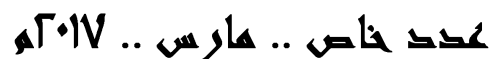

الالكتروني يعتمد بِّ نجاحهه علي مدي تفاعل الميدان الجامعي معه ، وملدى إقبال

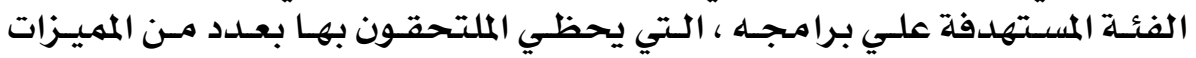

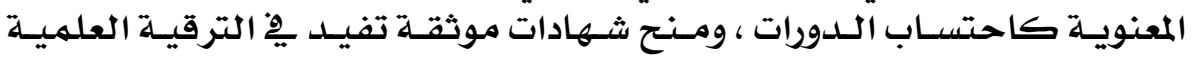

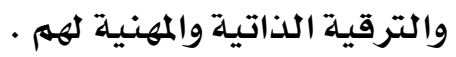
• المحور الثـاني: دور التسدريب الالكترونسي في تنميسة أعضساء هيئسة التسدريس بالجاهعات

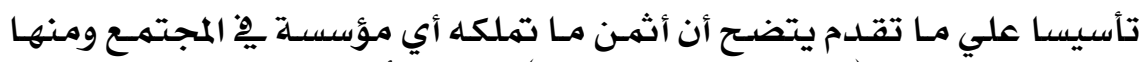

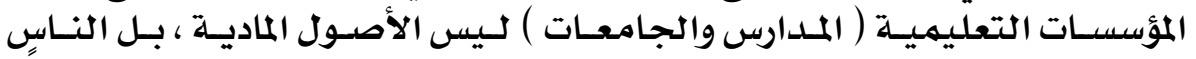

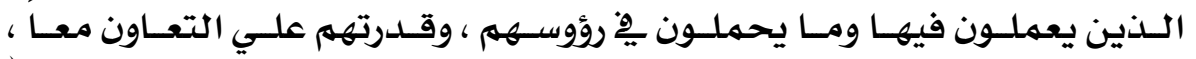

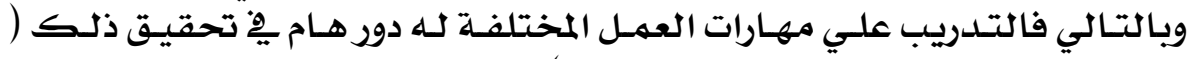

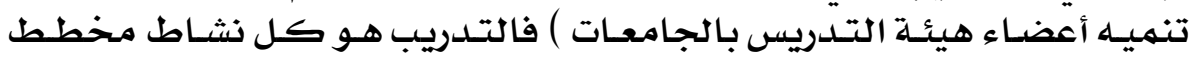

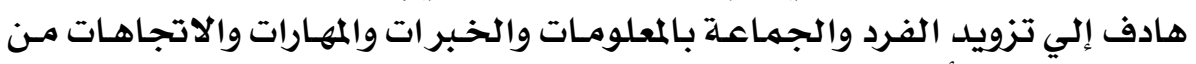

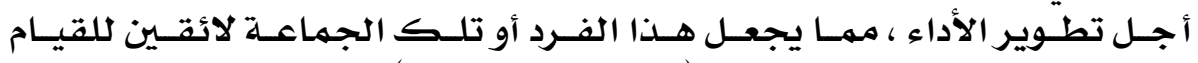

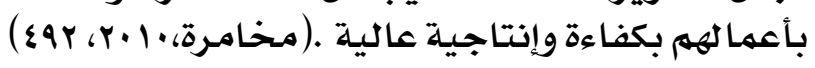

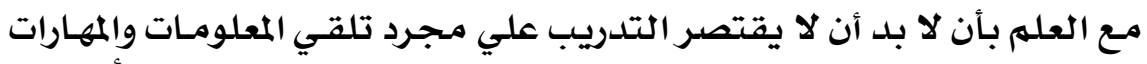

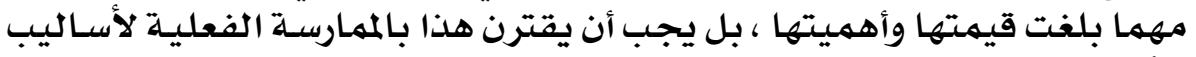

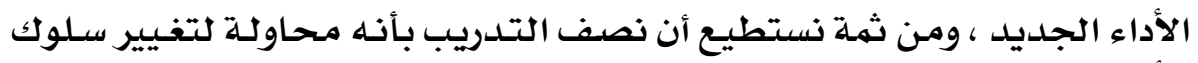

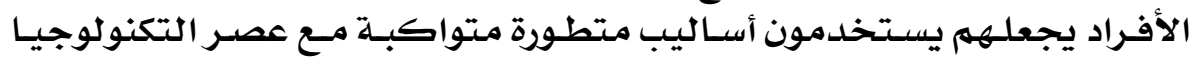

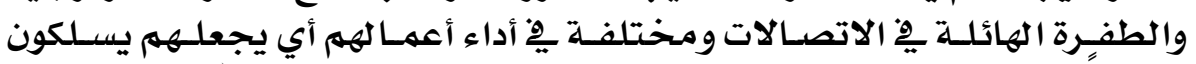

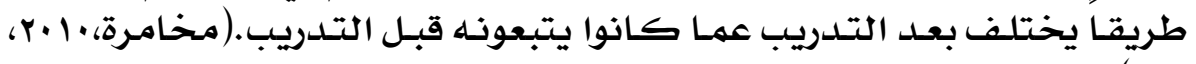

(194

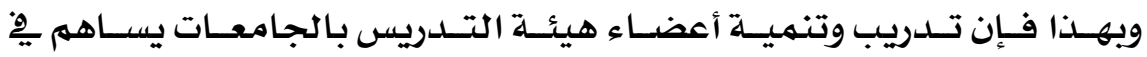

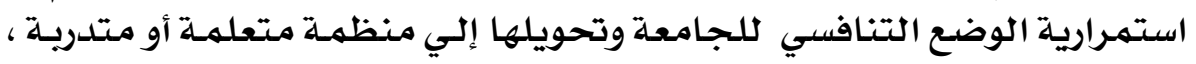

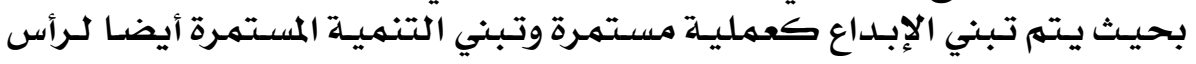

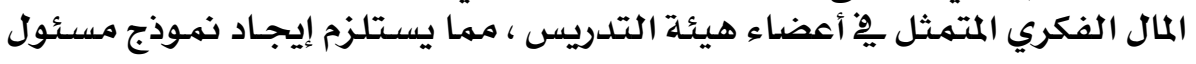

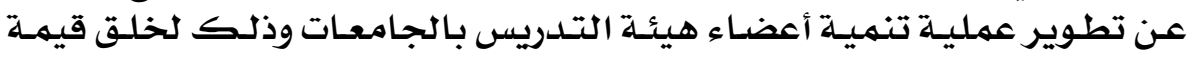

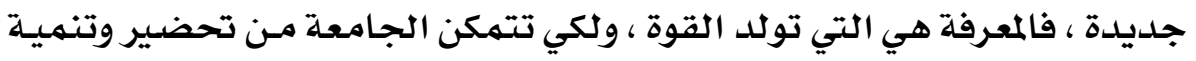

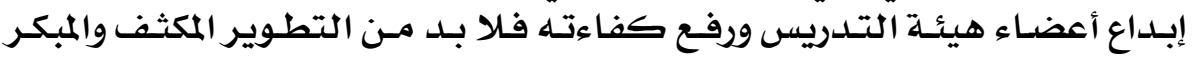

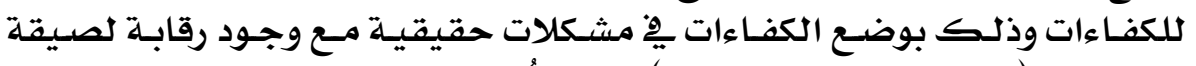

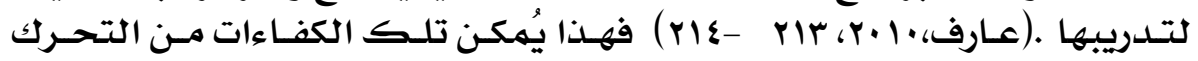

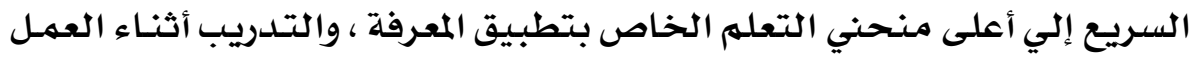

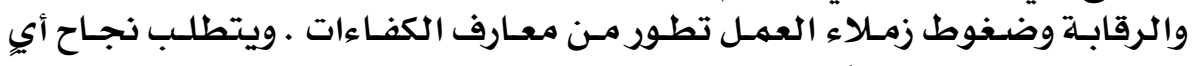

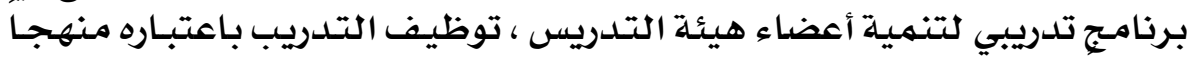

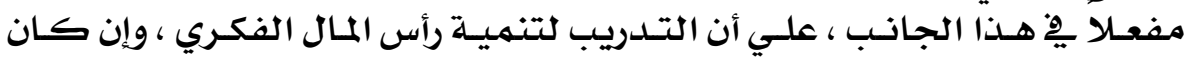

\section{rr}




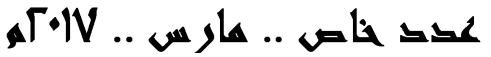

ينطلق من المنظومـة التدريبيـة المألوفة نفسـها ( تحلديد الاحتياجـات التدريبيـة ،

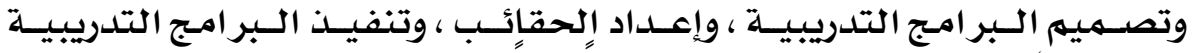
وتقييهها ) إلا أنه ينبغي أن يكون منختلفا جدا مـن حيث النوعيـة .

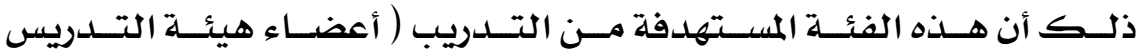

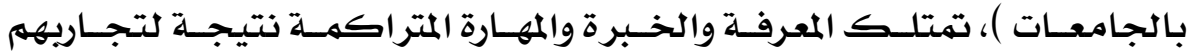

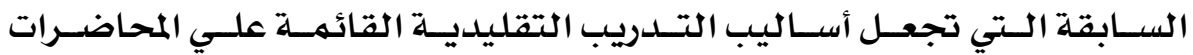

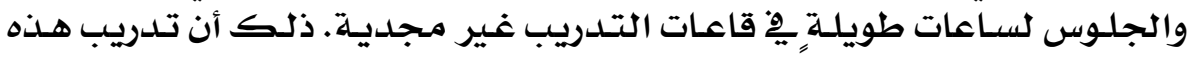

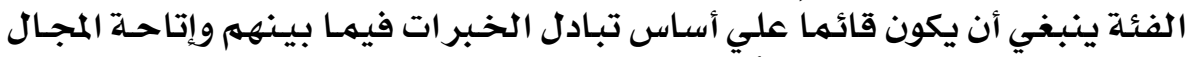

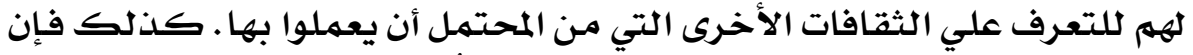

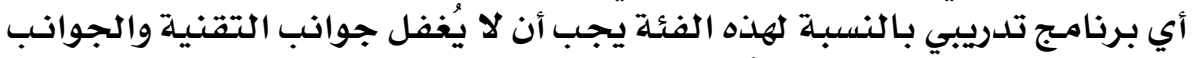

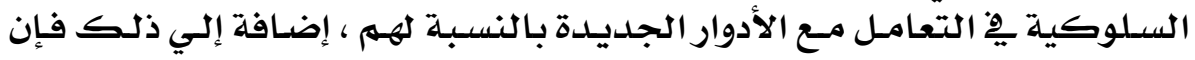

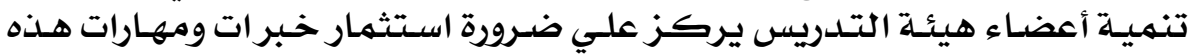

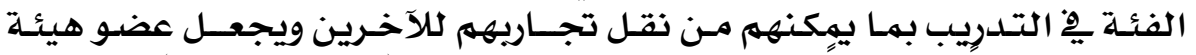

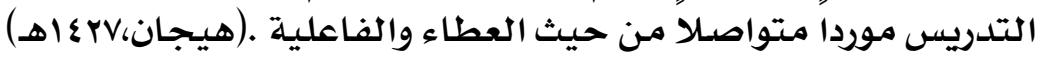

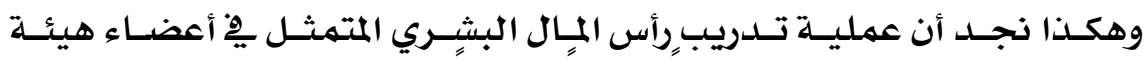

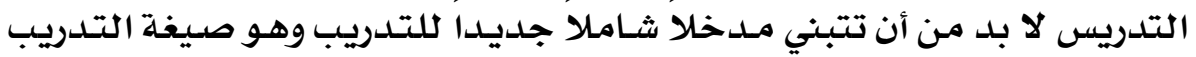

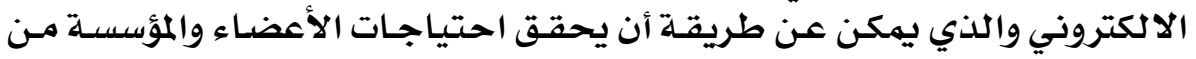

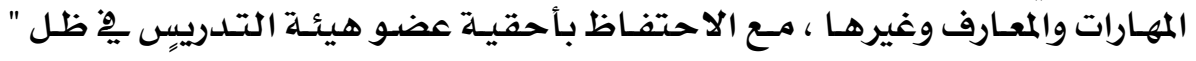

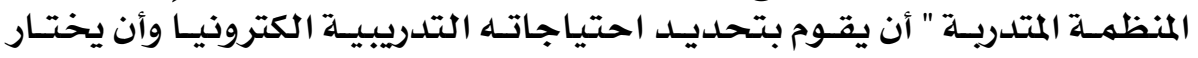

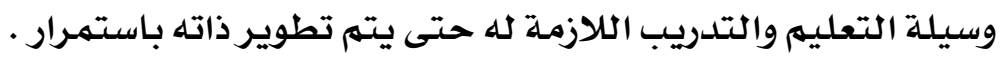

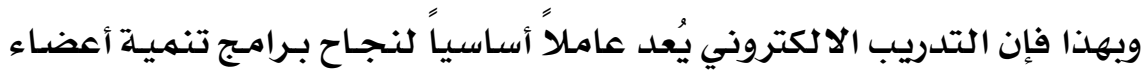

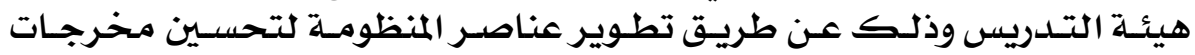

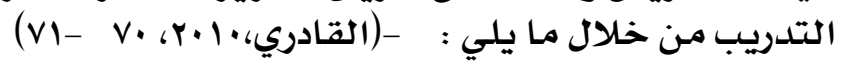

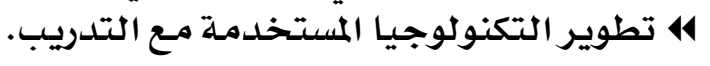

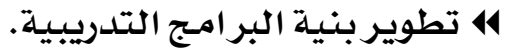
ه 14

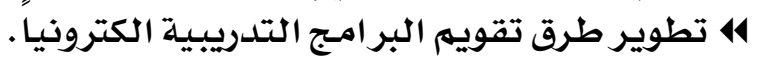

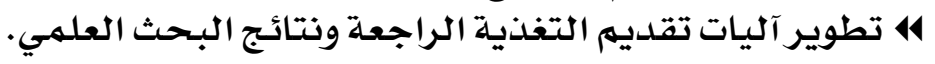

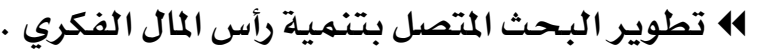

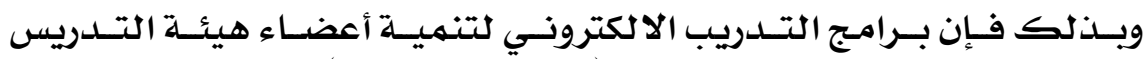

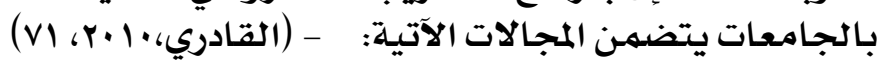

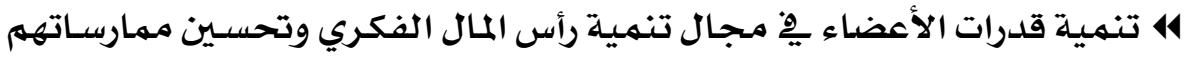
العمليـة.

\section{MrY}


4ه تنمية قدراتهم البحثية.

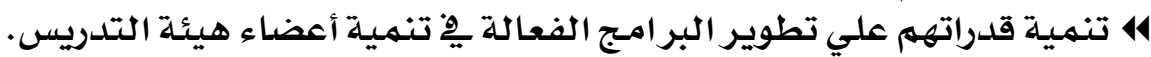

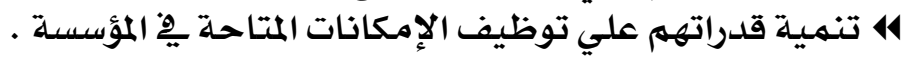

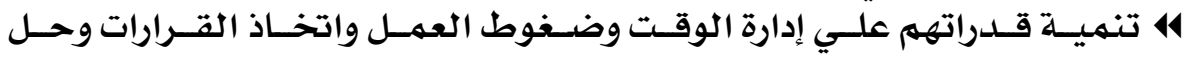

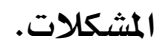

4 تنمية قدراتهم علي توظيف التكنولوجيا الحديثة بشكل فعال يِّ برامج تنميـة أعضاء هيئة التدريس.

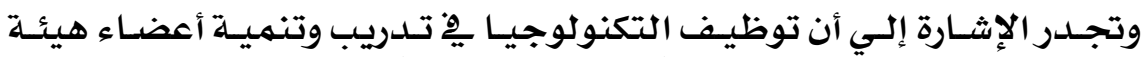

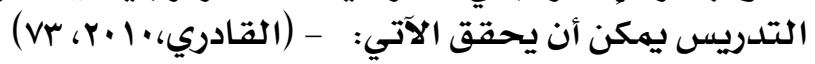

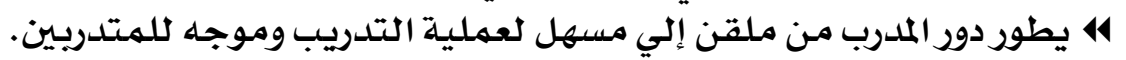

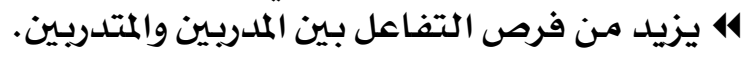

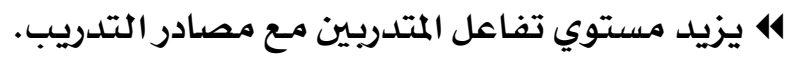

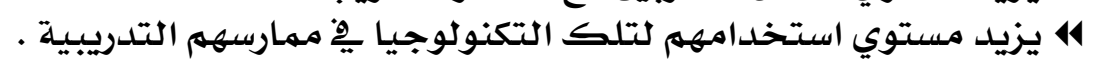

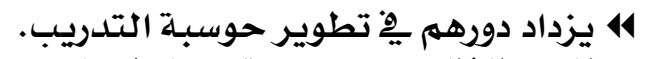

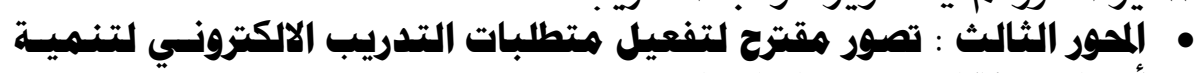

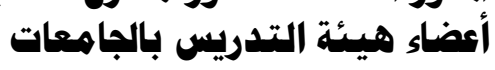

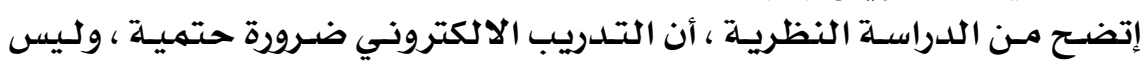

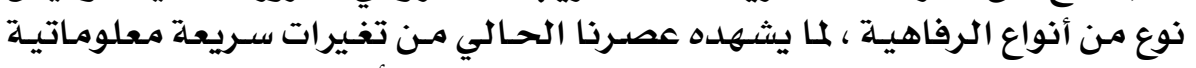

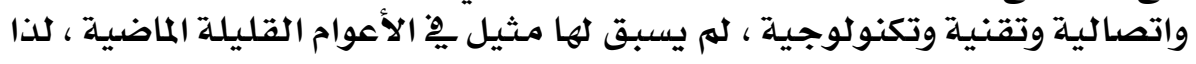

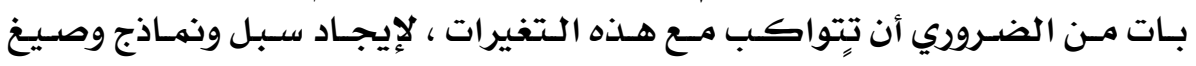

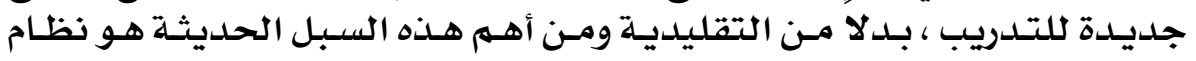

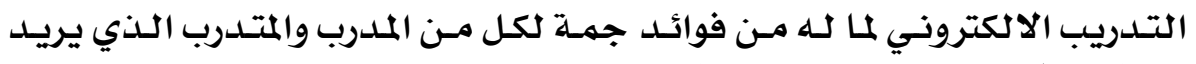

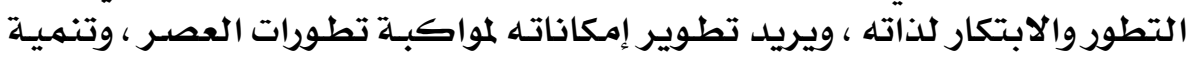

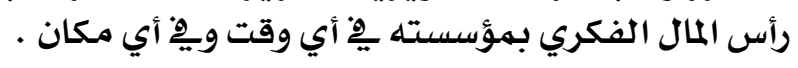

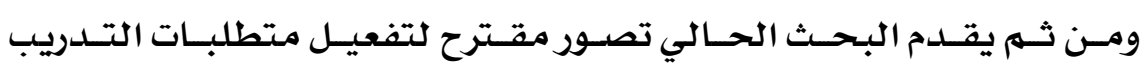

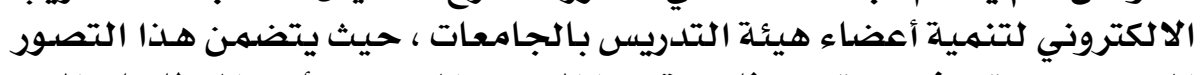

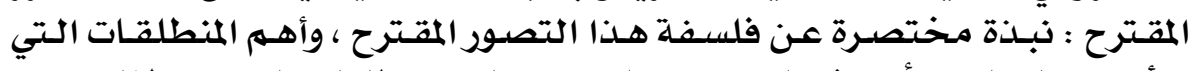

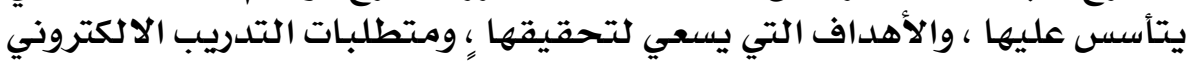

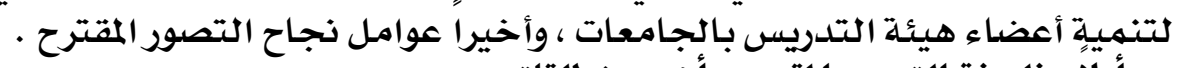

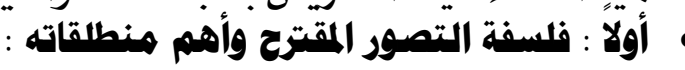

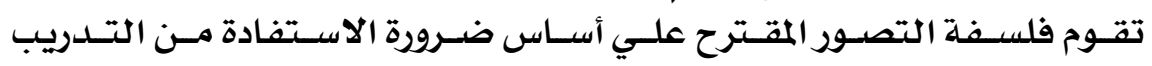

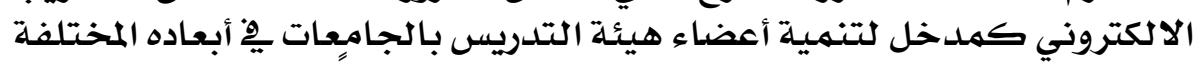

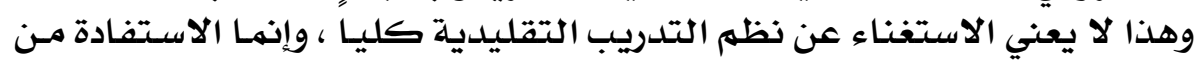

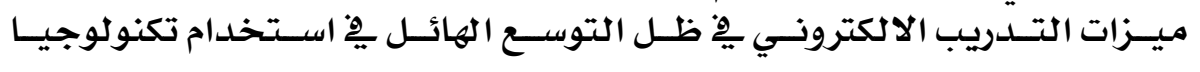

\section{YMY}




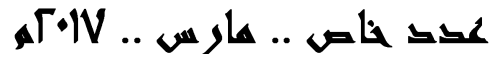

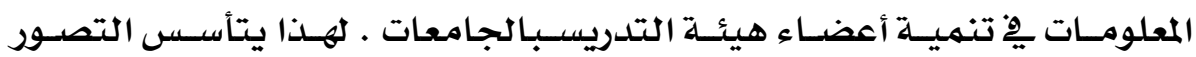

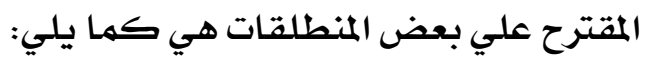

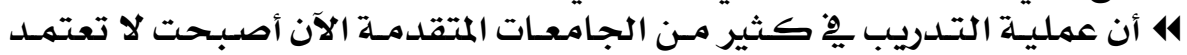

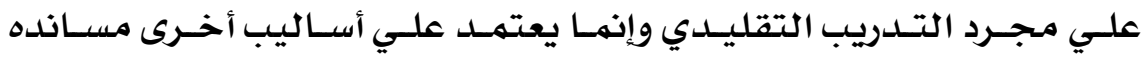

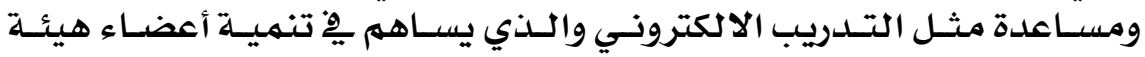

$$
\text { التدريسبالجامعات. }
$$

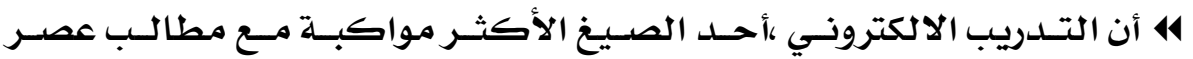

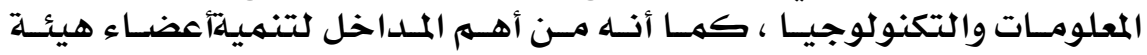

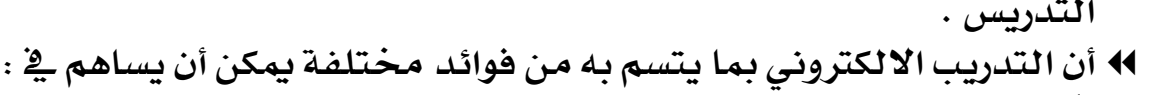

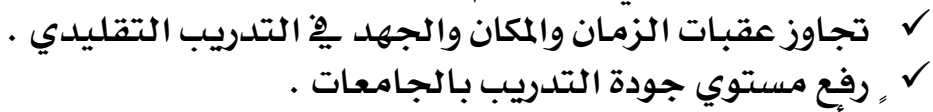

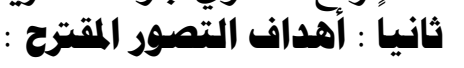

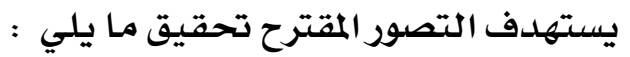

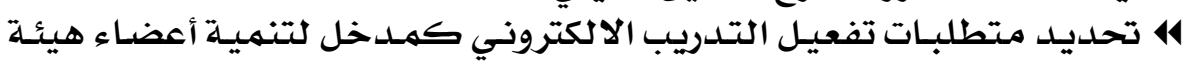

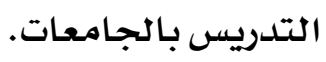

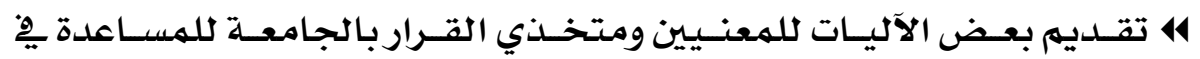

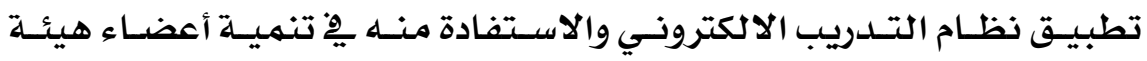
التدريسبالجامعات.

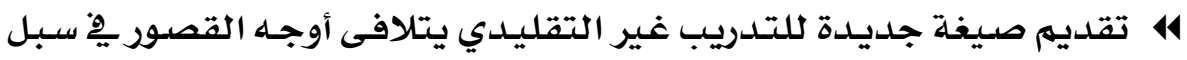

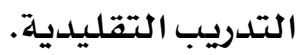

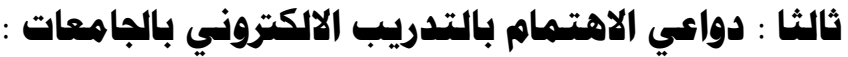

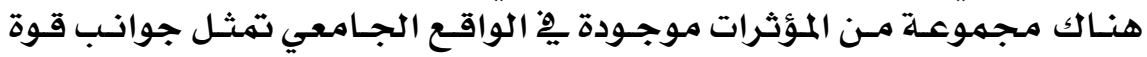

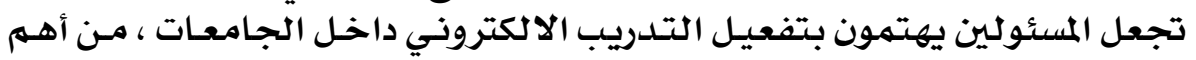

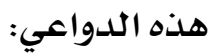

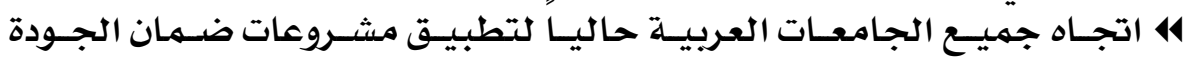

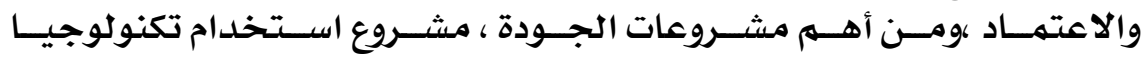
المعلومات.

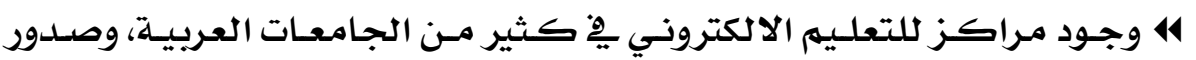

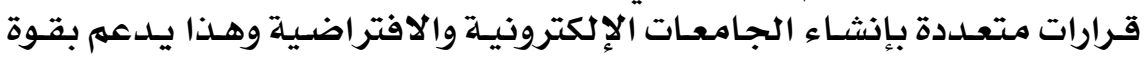

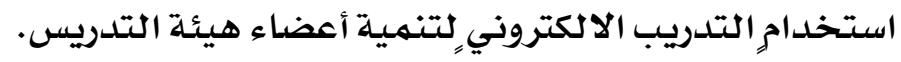

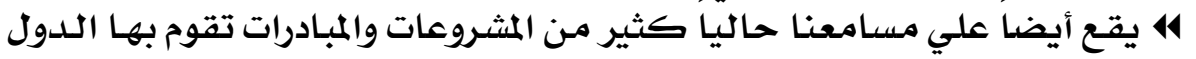

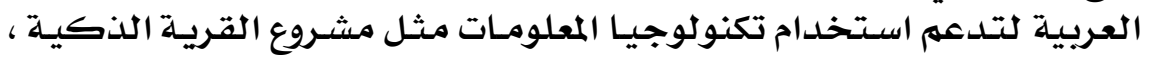

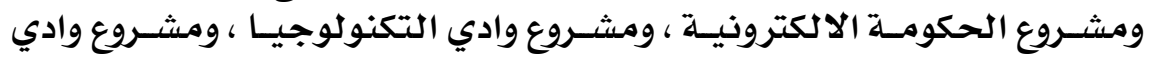

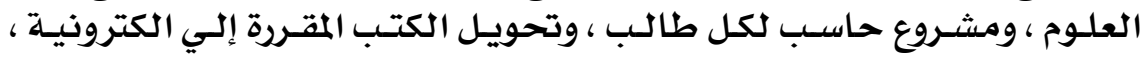

\section{$r \mu \varepsilon$}




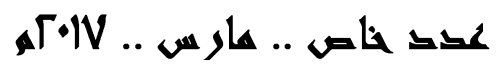

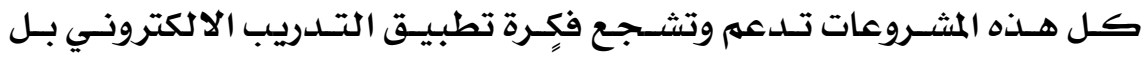

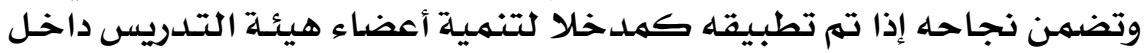

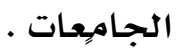

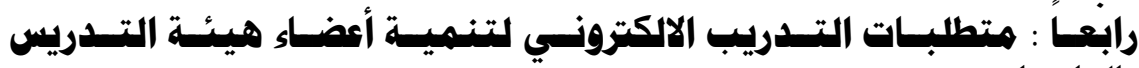

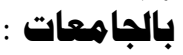

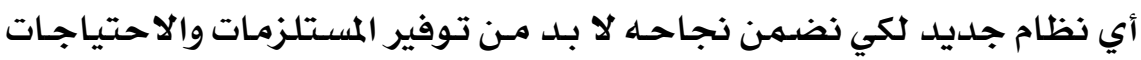

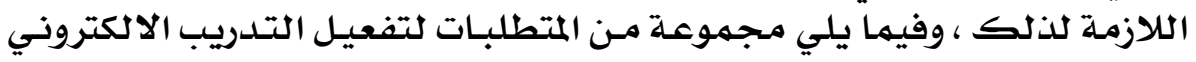

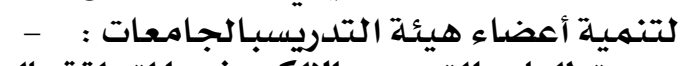
هتطالبات التدريب الالكتزوني المتعلقة بالجوانب البتانب البشرية بالجامعة:

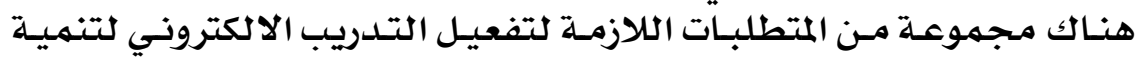

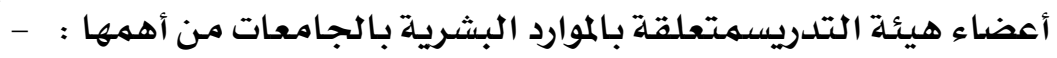

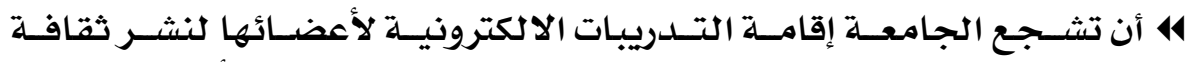

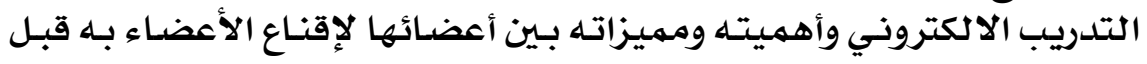

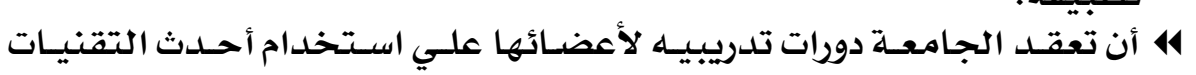

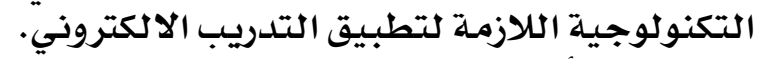

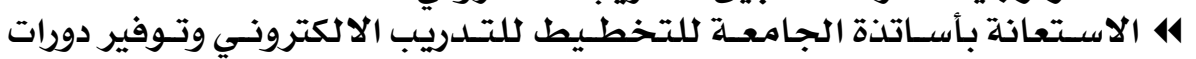

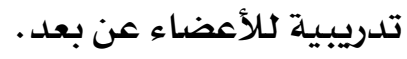

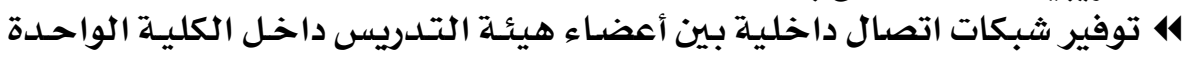

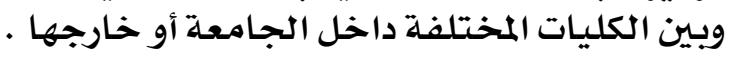

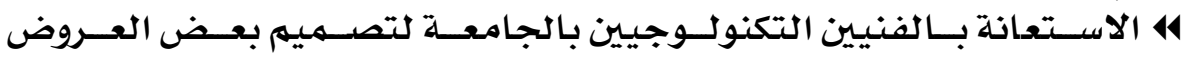

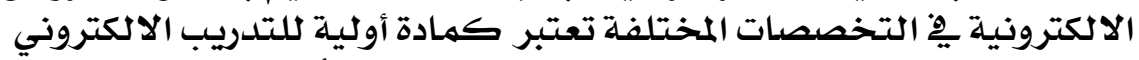

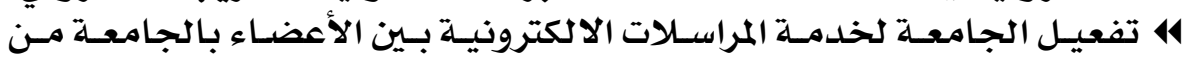

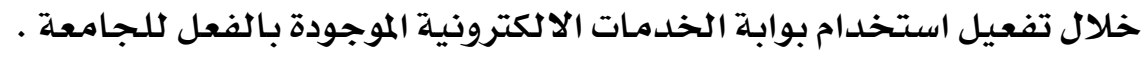

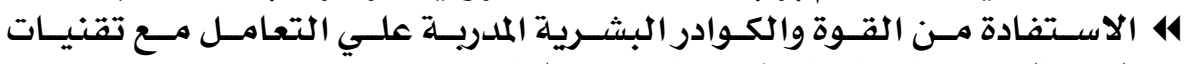

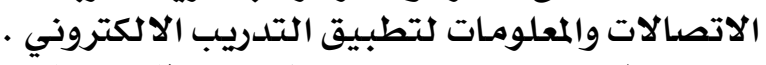

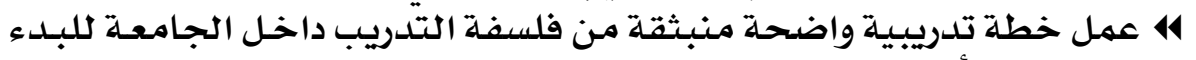

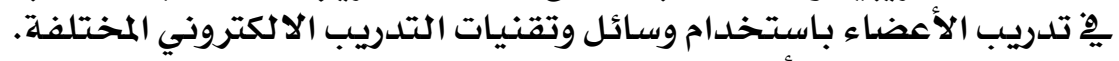

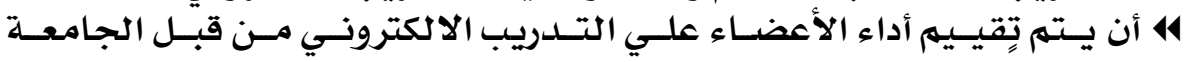

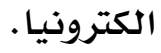

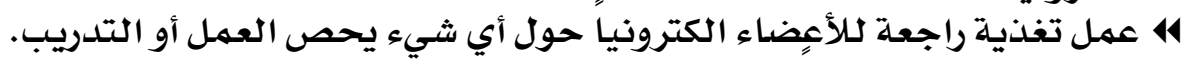

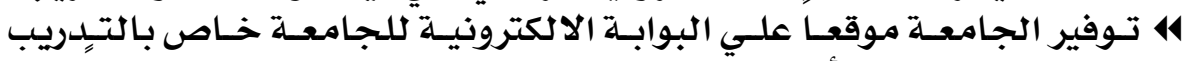

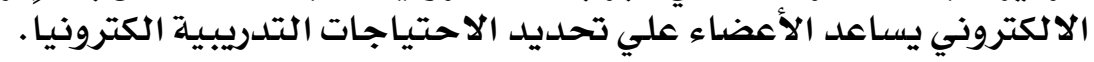

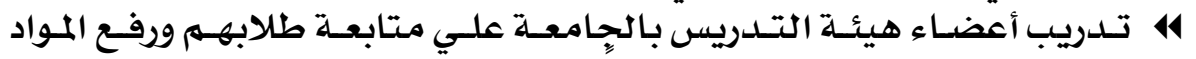

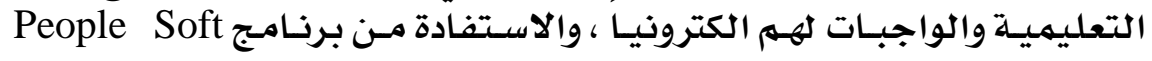
وبرنامجBlack board هِّ ذلك.

\section{YHO}




\section{عقد خاص .. عار س .. VIיזم,}

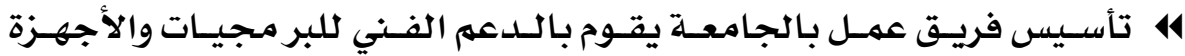

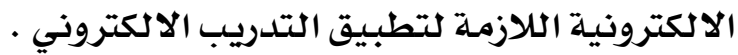

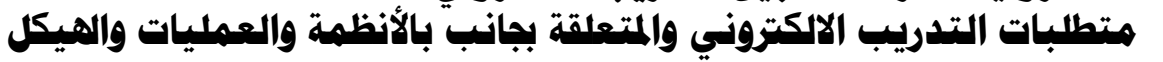

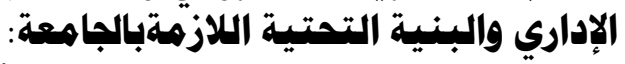

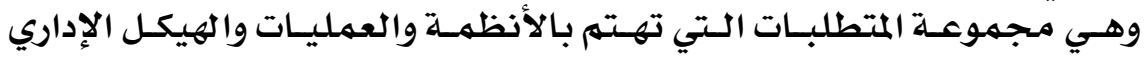

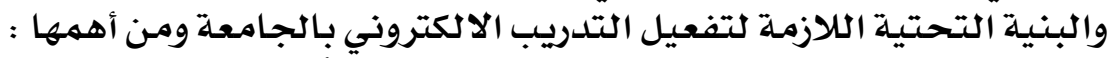

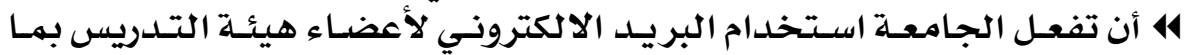

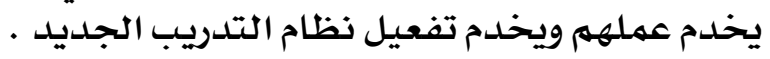

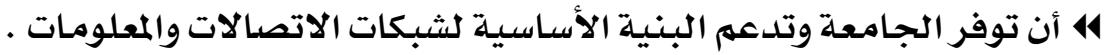

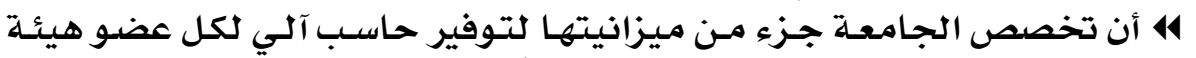

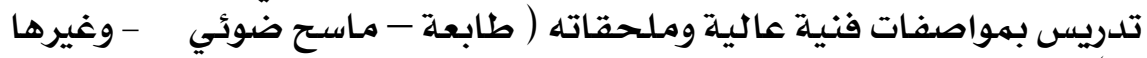

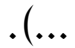

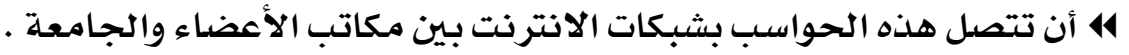

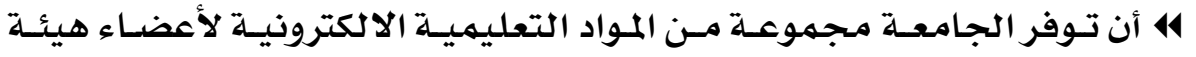

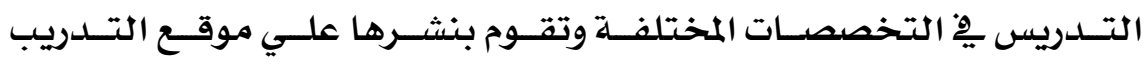

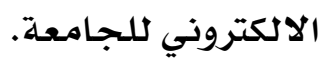

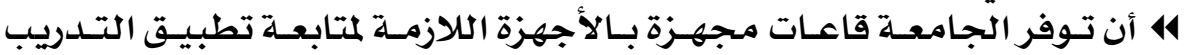

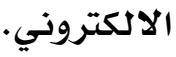

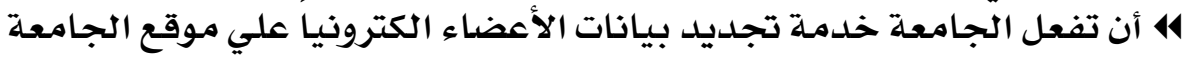

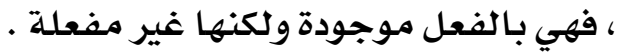

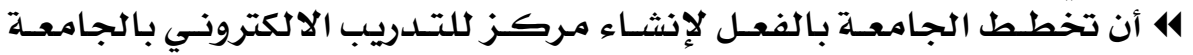

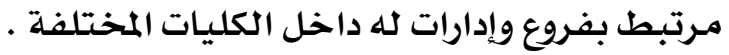

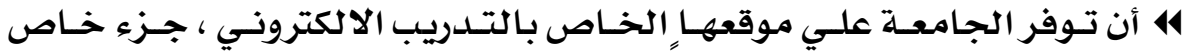

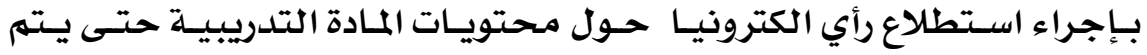

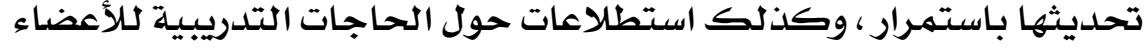

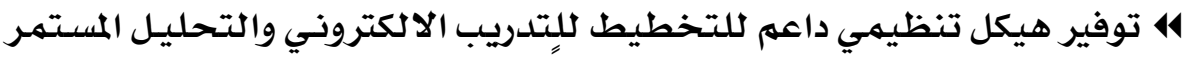

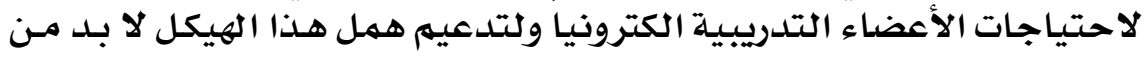

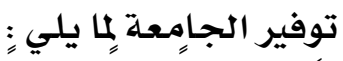

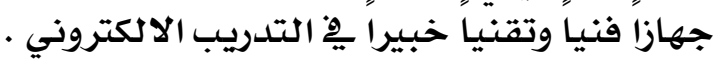

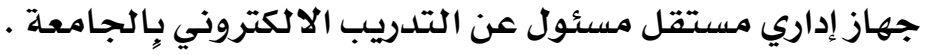

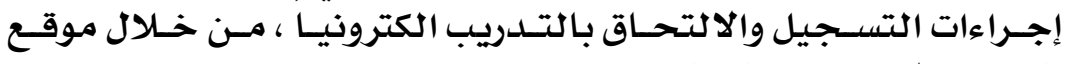

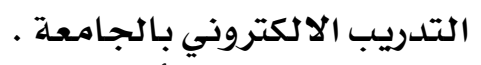

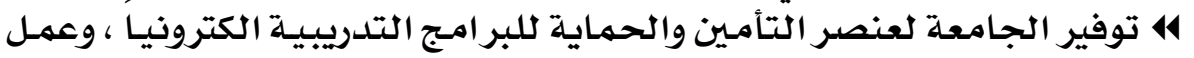

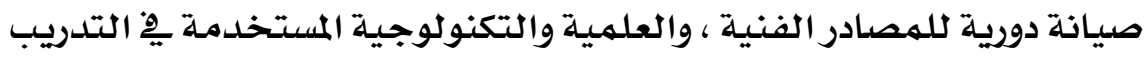

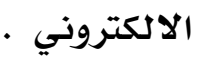

\section{rry}




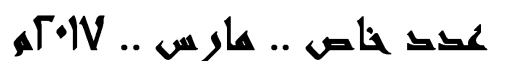

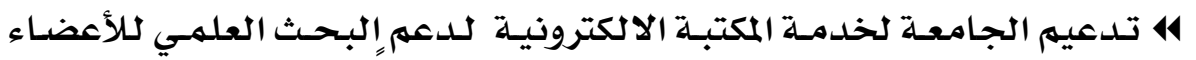

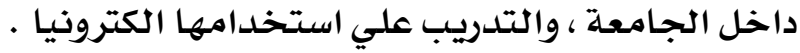

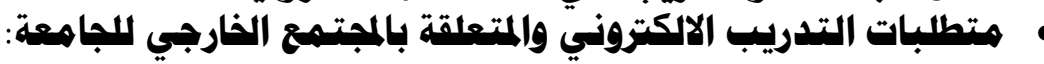

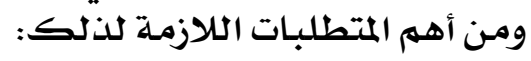

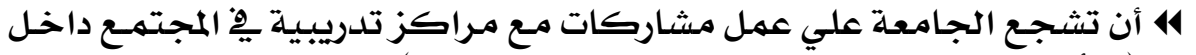

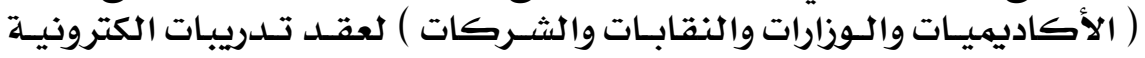

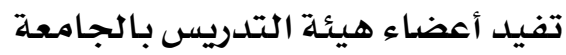

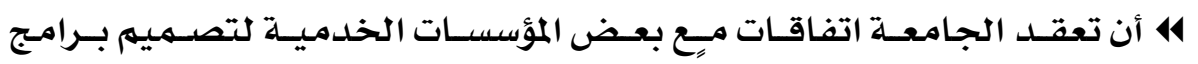

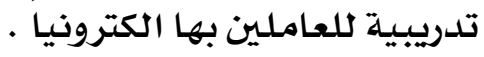

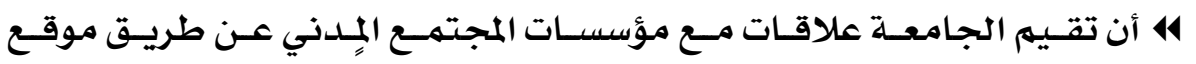

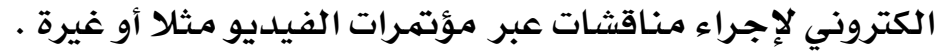

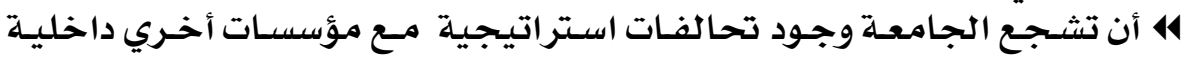

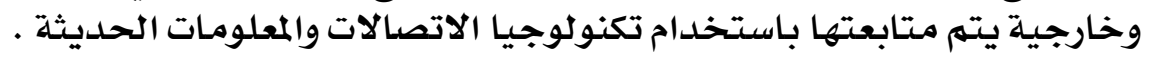

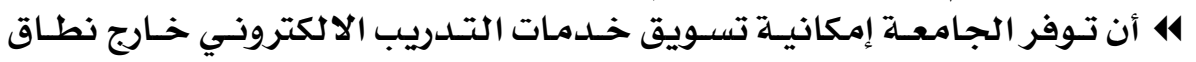

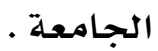
4 أن تستقبل الجامعة شكاوي العملاء من داخل وخـارج الجامعة الكترونياً علي

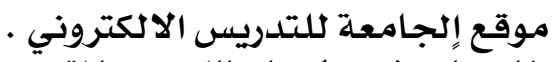

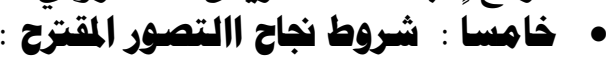

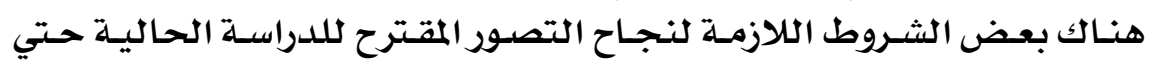

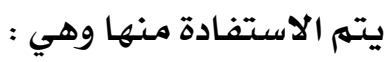

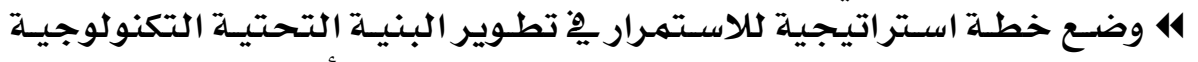

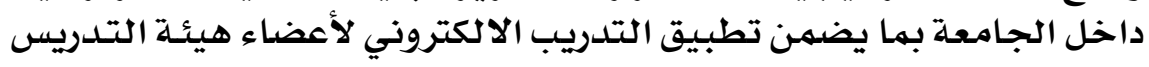

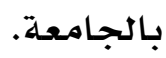
4 تشكيل جهاز إداري مستقل للتدريب الالكتروني بالجامعة لوضع هذا لهذه الخطة ،

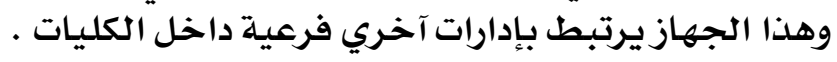

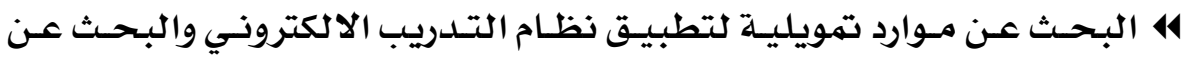

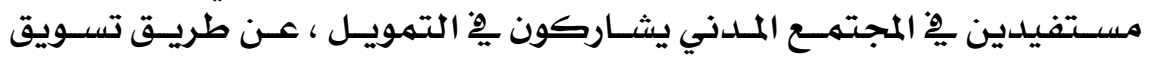

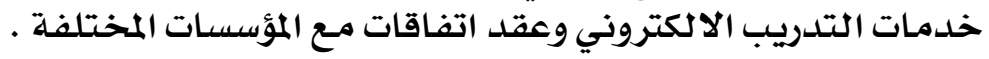

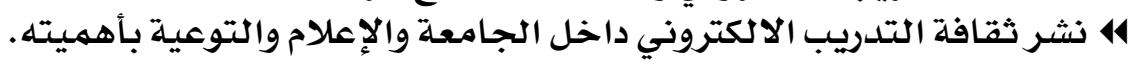

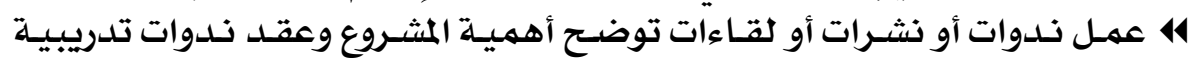

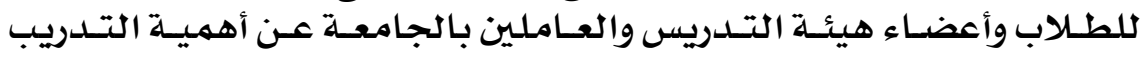

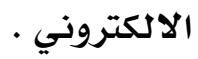
414 عمل نظام سليم لتقويم ومتابعة تجربة التدريب الالكتروني .

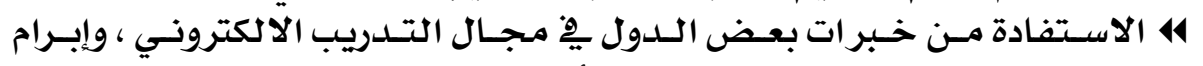

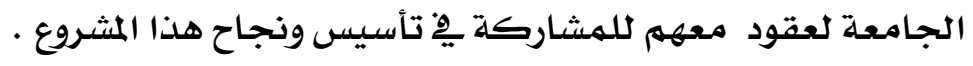

\section{rrV}




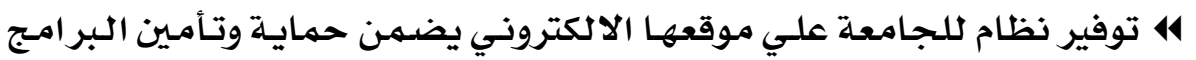

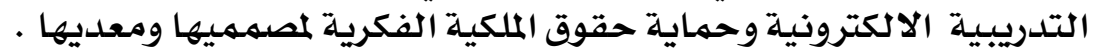

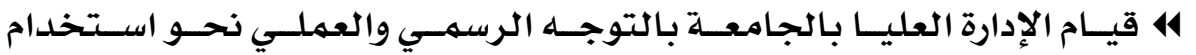

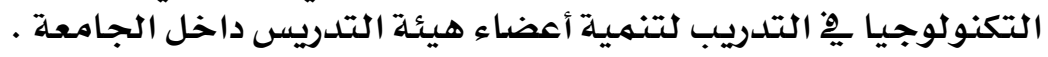

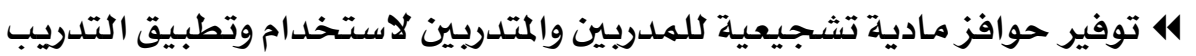

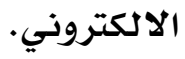

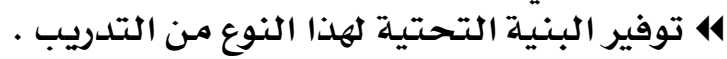

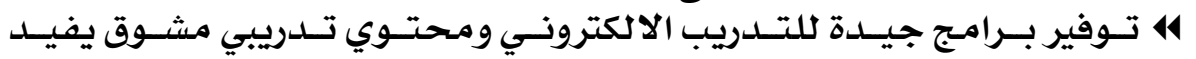

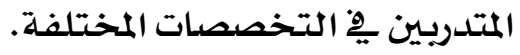

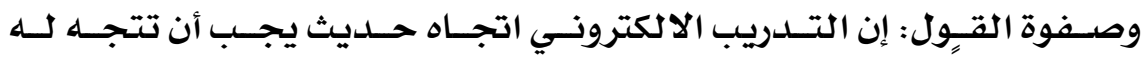

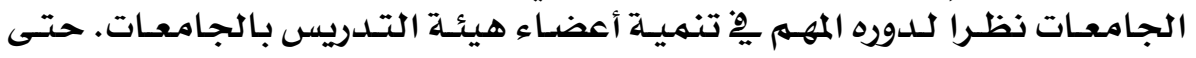

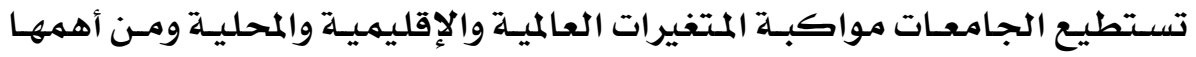

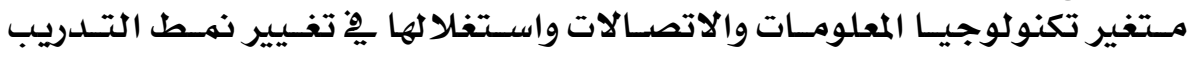
التقليدي.

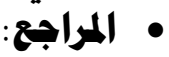

1

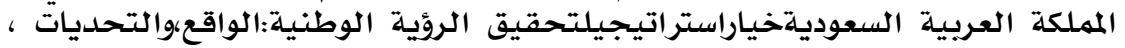

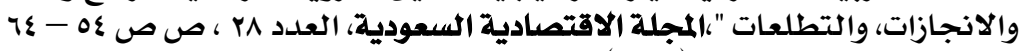

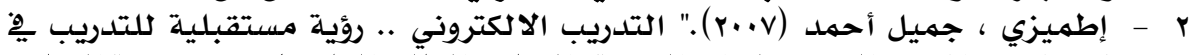

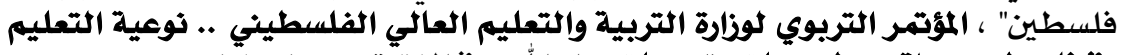

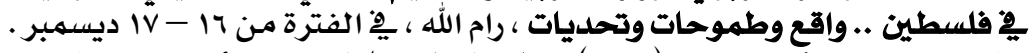

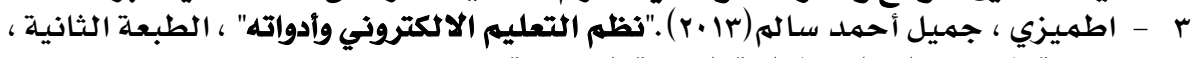

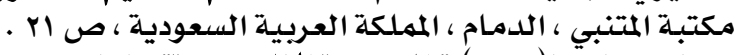

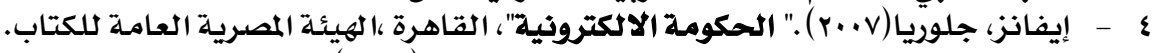

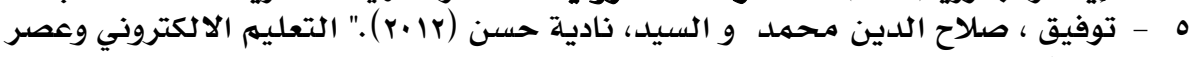

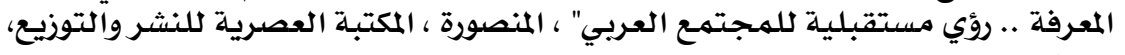

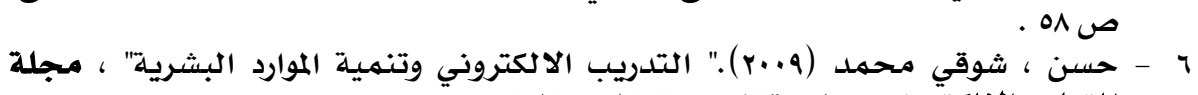

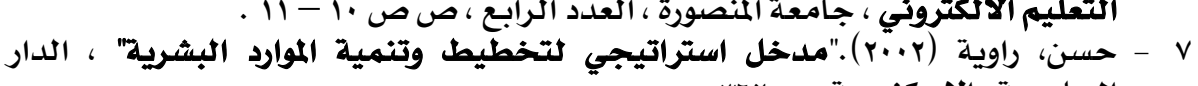

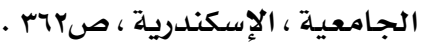

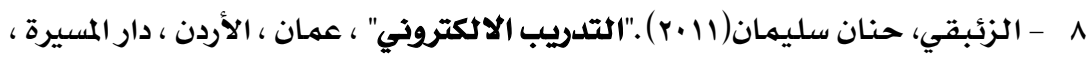

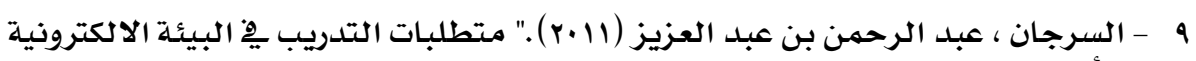

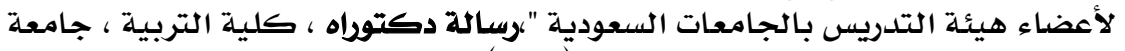

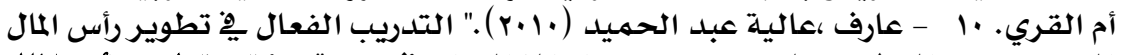

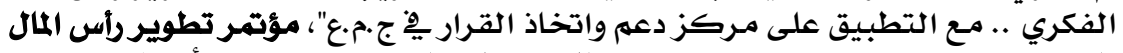

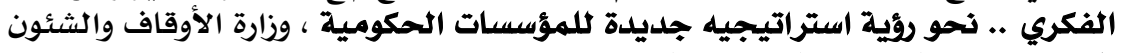

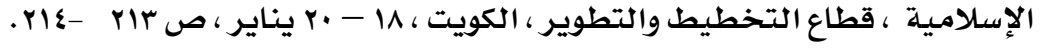

\section{MrA}




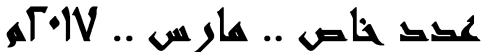

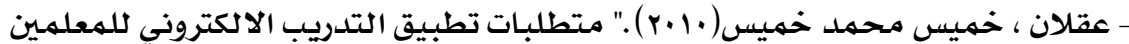

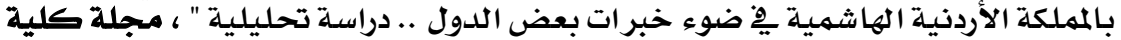

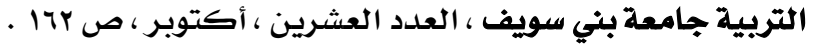

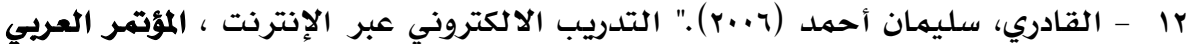

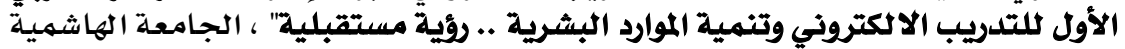

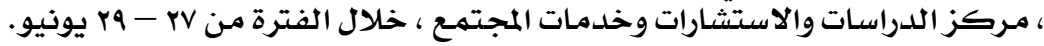

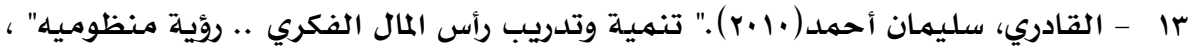

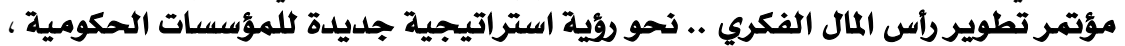

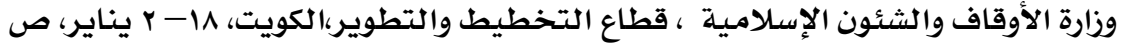

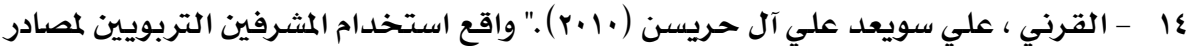

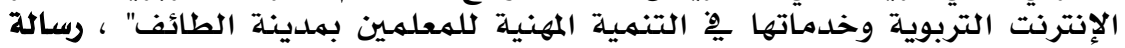

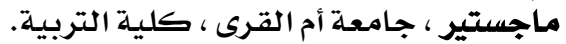

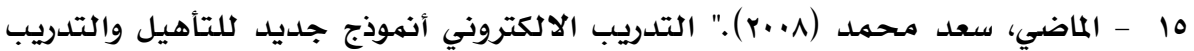

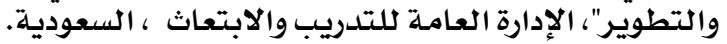

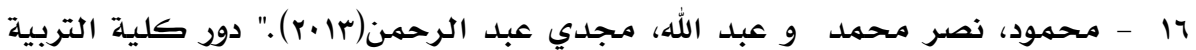

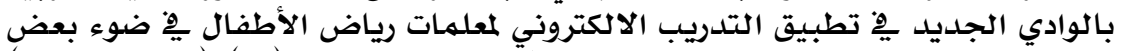

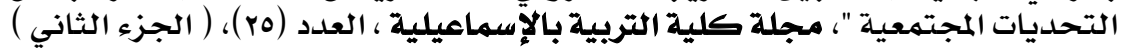

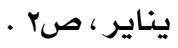

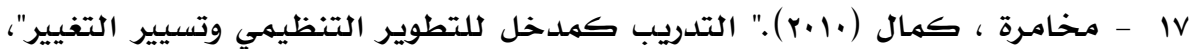

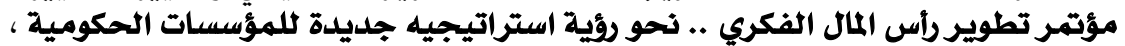

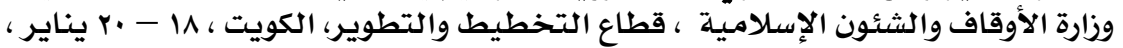

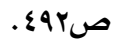

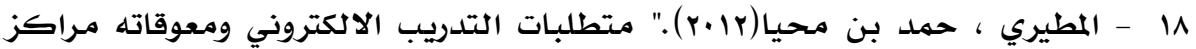

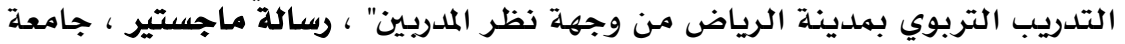

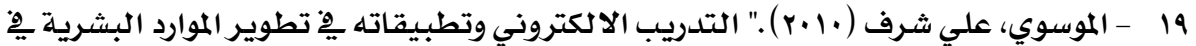

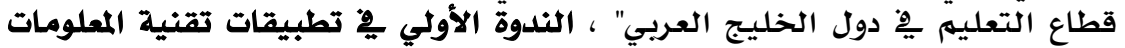

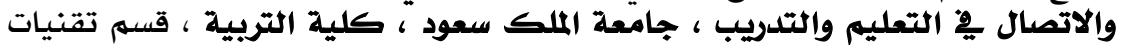

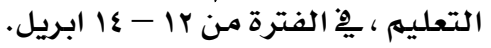

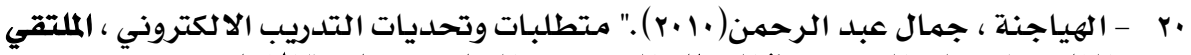

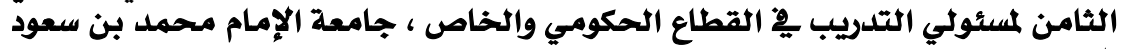

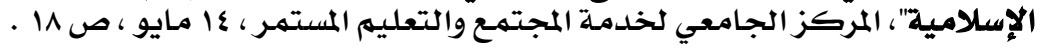

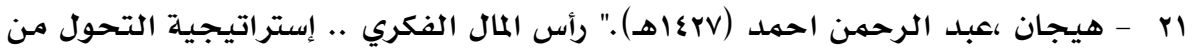

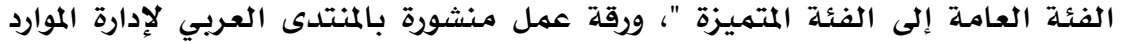
البشريـة.

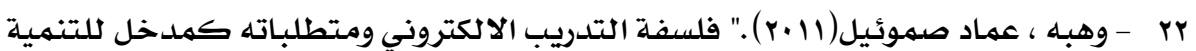

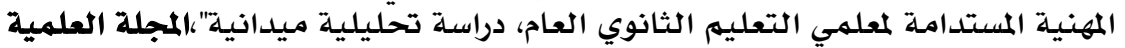

\section{rrq}




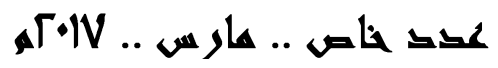

لكلية التربية،جامعة أسيوط،المجلدالسابع والعشرون،العددالأول،الجزءالأول،يناير،ص r.V-

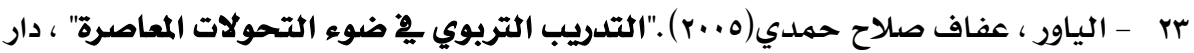

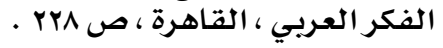

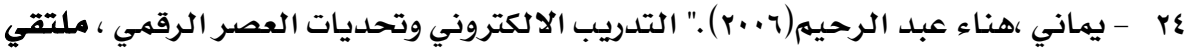

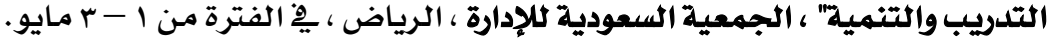

25-Clark , Alan(2004)." Much to learn About E-learning", Adults learning,Vol.15, Issue 5 ,pp.26- 27.

26-Irani ,Tracy(2001)." Developing a Model Distance Education Faculty .. Training program", University of Florida.

27-Kilby, Tim (2001)." The Direction of web - based Training..organization" , MCB University Press, Vol.8, No.9.

橉潾潾 